UCRL-ID-119659

\title{
Lithogenic and Cosmogenic Tracers in Catchment Hydrology
}

\author{
Gregory J. Nimz \\ Isotope Geochemistry Section \\ Nuclear Chemistry Division \\ Lawrence Livermore National Laboratory
}

This is an informal report intended primarily for internal ox limited external distribution. The opinions and conclusions stated are those of the author and may or may not be those of the Laboratory.

Work performed under the auspices of the U.S. Department of Energy by the Lawrence Livermore National Laboratory under Contract W-7405-Eng-\$8.

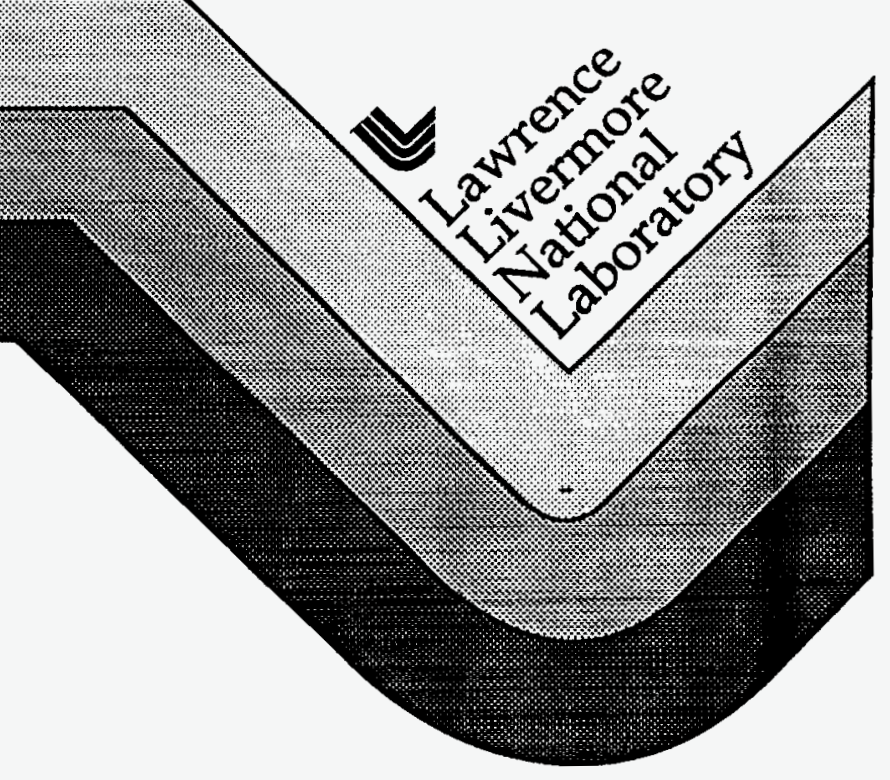

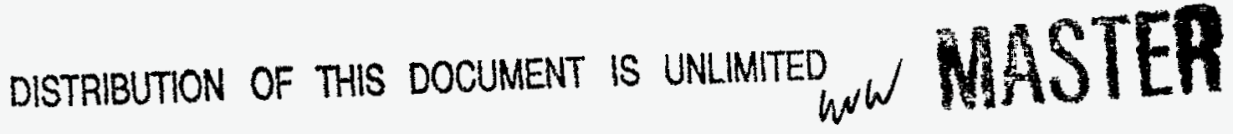




\section{DISCLAIMER}

This document was prepared as an account of work sponsored by an agency of the United States Government. Neither the United States Government nor the University of California nor any of their employees, makes any warranty, express or implied, or assumes any legal liability or responsibility for the accuracy, completeness, or usefulness of any information, apparatus, product, or process disclosed, or represents that its use would not infringe privately owned rights. Reference herein to any specific commercial products, process, or service by trade name, trademark, manufacturer, or otherwise, does not necessarily constitute or imply its endorsement, recommendation, or favoring by the United States Government or the University of California. The views and opinions of authors expressed herein do not necessarily state or reflect those of the United States Government or the University of California, and shall not be used for advertising or product endorsement purposes.

This report has been reproduced

directly from the best available copy.

Available to DOE and DOE contractors from the Office of Scientific and Technical Information

P.O. Box 62, Oak Ridge, TN 37831

Prices available from (615) 576.8401, FTS 626-8401

Available to the public from the

National Technical Information Service

U.S. Department of Commerce

5285 Port Royal Rd.,

Springfield, VA 22161 


\section{DISCLAIMER}

Portions of this document may be illegible in electronic image products. Images are produced from the best available original document. 


\section{Introduction}

A variety of physical processes affect solute concentrations within catchment waters. The isotopic compositions of the solutes can indicate which processes have determined the observed concentrations. These processes together constitute the physical kistory of the water, which is one of the primary concerns in hydrology. Many groundwater solutes are derived as a result of interaction between the water and the rock and/or soil within the system. These are termed "lithogenic" solutes. The isotopic compositions of these solutes provide information regarding rock-water interactions. Many other solutes have their isotopic compositions determined both internally and externally to the catchment system. Important members of this group include solutes that have isotopic compositions produced by atomic particle interactions with other nuclides. The source of the atomic particles can be cosmic radiation (producing "cosmogenic" nuclides in the atmosphere and land surface), anthropogenic nuclear reactions (producing "thermonuclear" nuclides), or radioactive and fission decay of naturally-occurring elements, such as $U$ and $T h$ (producing "in-situ" lithogenic nuclides in the deep subsurface). Current language usage often combines all of the atomic particle-produced nuclides under the heading "cosmogenic nuclides", and for simplicity we will often follow that usage here, although always clearly indicating which variety is being discussed. This paper addresses the processes that affect the lithogenic and cosmogenic solute compositions in groundwater, and how these compositions can therefore be used in integrative ways to understand the physical history of groundwater within a catchment system.

The concept of a "system" is important in catchment hydrology. By focusing on catchment systems the attempt is being made to delimit the system under consideration. A catchment is the smallest landscape unit that can both participate in all of the aspects of the hydrologic cycle and also be treated as a mostly closed system for mass balance considerations. Because chemical mass balance within catchments generally involves lithogenic elements, much of this paper concerns mass balance. Examination of the isotopic compositions of solutes provides a better understanding of the variety of processes controlling mass balance. It is with this approach that we examine the variety of processes occurring within the catchment system, such as weathering and soil production, hydrograph separation, movement of soil pore water, groundwater flow paths, and basinal water balance. 
In this paper, the term "nuclide" will be used when referring to a nuclear species that contains a particular number of protons and neutrons. The term is inspecific to any element. The term "isotope" will be used to distinguish nuclear species of a given element (atoms with the same number of protons). That is to say, there are many nuclides in nature - for example, ${ }^{36} \mathrm{Cl},{ }^{87} \mathrm{Sr},{ }^{238} \mathrm{U}$; the element $\mathrm{Sr}$ has four naturally-occurring isotopes $-{ }^{84} \mathrm{Sr},{ }^{86} \mathrm{Sr},{ }^{87} \mathrm{Sr}$, and ${ }^{88} \mathrm{Sr}$.

\section{Processes That Affect Lithogenic and Cosmogenic Isotopic Compositions in Catchment Systems}

\section{Lithogenic and Cosmogenic Nuclides: General Principles}

Lithogenic and Cosmogenic Nuclides Used in Catchment Analysis. Solutes commonly derived from rocks and soils that have isotopic compositions useful in hydrology include: 1) those that have varying isotopic ratios due to radioactive decay of other nuclides: $\mathrm{Sr}, \mathrm{Pb}, \mathrm{Nd}$, and U-decay series elements; 2) those that have varying isotopic ratios due to fractionation by natural processes: $\mathrm{Li}, \mathrm{B}, \mathrm{C}, \mathrm{N}$, $\mathrm{S}, \mathrm{Cl}$, and perhaps $\mathrm{Fe}$ (hydrogen and oxygen are in this group as well, although they are not "solutes"); and 3) those that have varying isotopic ratios due to production of nuclides in nature by induced changes in the nucleus of the atom: $\mathrm{Be}, \mathrm{Al}, \mathrm{Cl}, \mathrm{Ca}$, and I. In this paper we will focus on the isotopes of $\mathrm{Sr}, \mathrm{Pb}, \mathrm{Nd}, \mathrm{Li}, \mathrm{Be}, \mathrm{B}, \mathrm{Cl}$, and $\mathrm{I}$, as well as the lithogenic aspects of the U-decay series: the ${ }^{234} \mathrm{U} / 238 \mathrm{U}$ ratios. Because the isotopes of $\mathrm{Nd}, \mathrm{Li}, \mathrm{Be}, \mathrm{B}$, and stable $\mathrm{Cl}$ have only recently been used in hydrology, they will be discussed under the heading "New Directions" in catchment groundwater studies.

The cosmogenic nuclides available for groundwater studies include ${ }^{3} \mathrm{H},{ }^{10} \mathrm{Be}$, ${ }^{14} \mathrm{C},{ }^{36} \mathrm{Cl},{ }^{41} \mathrm{Ca}$, and ${ }^{129} \mathrm{I}$. Except for ${ }^{3} \mathrm{H}$, all of these also have a lithogenic origin ("in-situ" production), and are listed above. We will mainly focus on ${ }^{36} \mathrm{Cl}$ and ${ }^{129} \mathrm{I}$ in this paper, although ${ }^{10} \mathrm{Be}$ and ${ }^{41} \mathrm{Ca}$ will be addressed in the "New Direction" section.

Origin of Lithogenic Nuclides in Groundwater: Mineral Reactions. Groundwater originating as precipitation is dilute to the extent that it is undersaturated in the minerals that make up the rock and soil. Under these unsaturated conditions, the 
minerals begin to react with the water until saturation is reached. Often, when several minerals are simultaneously reacting, the water will become saturated in minerals other than those dissolving. The saturated phases will likely precipitate from the water, leading to decreased saturation of those phases originally reacting and thereby continuing the dissolution process.

Two approaches are commonly used to assess mineral-water reactions: the "mass-balance" approach, and the "thermodynamic" or "reaction-path" approach. The mass balance approach models the reactions in the system on the basis of observed minerals and measured water solute concentrations. Garrels and MacKenzie (1967) were the first to make rigorous use of this approach, and it has been used often since that time (Cleaves et al., 1970; Miller and Drever, 1977a; Plummer and Back, 1980, Paces, 1983; Drever and Hurcomb, 1986). Garrels and MacKenzie were able to quantitatively demonstrate that solutes in groundwater within granitic rocks in the Sierra Nevada mountains were derived from reactions involving plagioclase, biotite, and alkali feldspar, the major mineral phases of the granitic rocks. Kaolinite and smectite, commonly observed "weathering" minerals, were products in the reactions.

The reaction-path approach models observed differences in solute concentrations within groundwaters on the basis of thermodynamic stabilities (Helgeson et al., 1969; Plummer et al., 1983). When the water passes from one lithology to another along a flowpath, the reaction-path approach provides a means of calculating the water-solute-rock reactions that would occur (i.e., that are thermodynamically favored). The mass-balance approach alone cannot make predictions concerning these reactions. In the reaction-path approach, the inferred minerals may not be known to exist in the system (due to, for example, the inability to obtain rock samples from depth), and water samples containing inferred intermediate solute concentrations may not have been collected. This is the typical situation in regional groundwater studies and often makes the reaction-path approach the most useful of the two. However, the two approaches are complimentary: the mass-balance approach cannot violate thermodynamic considerations, and the reaction-path approach cannot violate system mass-balance considerations. Further, the mass-balance approach can suggest the reaction equations to be used in ("tested" by) thermodynamic calculations. Whether thermodynamically favored reactions actually occur in a groundwater system can be tested by mass balance calculations involving measured solute concentrations. The 
most thorough studies combine the two approaches to model the chemical evolution of a groundwater system (e.g., Plummer et al., 1991a).

Origin of Lithogenic Nuclides in Groundwater: Trace Elements. Most of the nuclides of interest in groundwater studies are isotopes of elements that occur in trace concentrations in the minerals within the system. Their concentrations in the water are therefore also usually low. Neither the mass-balance nor the reactionpath approaches are able to completely characterize the solute concentrations of these types of trace elements. This is primarily because both approaches focus on mineral reactions, while trace elements are capable of entering the groundwater without such reactions occurring. These elements are not predominantly controlled by the stoichiometry of the minerals in the system. They can be leached or otherwise removed from the minerals without creating significant charge imbalances. They often reside within the crystal lattice in sites where "Pauling's Rules" are violated (Pauling, 1960), and are therefore easily replaced by other ions. Cation exchange between groundwater and minerals, especially sheet silicates, can significantly increase the trace element concentrations in waters without either dissolution or precipitation occurring. Many trace elements can be considered to be in solution within the crystal itself and therefore to exhibit Henry's Law behavior. The passage of the elements into the water is the result of the difference in chemical potential between the solid and the water; the elements diffuse into the water. Neither the mass-balance nor the reaction-path approaches are directly capable of modelling leaching, ion exchange, or diffusion.

However, both approaches can be useful in understanding some aspects of the trace element budgets in groundwater systems. When trace elements enter the groundwater as the result of chemical reactions, the resulting concentrations can be predicted based on the concentrations within the reacting mineral phases. For these predictions, it is necessary to have an understanding of the distribution affinity between any new minerals produced in the reaction and the groundwater (i.e., the Henry's Law proportionality constant, the water-mineral distribution coefficient). Recent additions to the mass-balance and reaction-path approaches have begun to consider the isotopic behavior of non-stoichiometric elements in the water-rock reactions (e.g., the mass-balance computer code NETPATH; Plummer et al., 1991b; Plummer et al., 1992). 
Models have also been developed that focus specifically on trace element behavior during water-rock interaction. Nabelek (1987) developed a model based on previous models of oxygen isotope behavior during hydrothermal processes. Banner and Hanson (1990) developed equations for calculating simultaneous isotopic and trace element variations during the interaction between minerals and groundwater. These equations incorporate mineral-water distribution coefficients and fractionation factors for the isotopes of the elements. They rely on mass balance in the sense that concentrations within, and masses of, minerals must balance concentrations within, and masses of, groundwater. However, in that they are not based on dissolution or reaction equilibria, they lack the useful stoichiometric constraints present in the mass balance approach of Garrels and MacKenzie (1967). Nonetheless, they can be valuable when used in conjunction with either the massbalance or the reaction-path approaches (Banner et al., 1990; Musgrove and Banner, 1993).

Origin of Isotopic Variations: Radiogenic Nuclides. Many elements have isotopes that are produced in nature through the radioactive decay of parent nuclides. The daughter nuclides are termed "radiogenic". Although we speak of "parent" and "daughter" nuclides, there is really only one atom involved in the decay: the daughter atom is the same atom as the parent, only after decay it has a different number of neutrons in its nucleus. The change in the number of neutrons can occur in a variety of ways. A neutron can "release" an electron, thereby becoming positive in charge, a proton. The number of protons in the nucleus is therefore increased by one. This is called beta decay (an electron is a "beta" particle). A neutron can be formed in the nucleus by the "capture" of an electron by a proton, thereby becoming neutral in charge. The number of protons in the nucleus is therefore decreased by one. This is called beta capture, or electron capture. A nucleus can discharge an alpha particle, which is composed of two neutrons and two protons. This is called alpha decay. These three forms of radioactive decay are by far the most common. Although there are several other forms of decay, none of them produce the nuclides that we will discuss in this paper. The nuclide ${ }^{87} \mathrm{Sr}$ is produced by beta decay of ${ }^{87} \mathrm{Rb}$; ${ }^{143} \mathrm{Nd}$ is produced by alpha decay from ${ }^{147} \mathrm{Sm}$; ${ }^{234} \mathrm{U}$ is produced from ${ }^{238 \mathrm{U}}$ through two short-lived intermediate nuclides $\left({ }^{234} \mathrm{Th}\right.$, produced by alpha decay from ${ }^{238} \mathrm{U}$, and ${ }^{234} \mathrm{~Pa}$, produced by beta decay from ${ }^{234} \mathrm{Th}$; another beta decay then produces $234 \mathrm{U}$ ). The radiogenic lead isotopes are the final product of a long series of 
beta and alpha decays originating from ${ }^{232} \mathrm{Th}$ (producing ${ }^{208} \mathrm{~Pb}$ ), $235 \mathrm{U}$ (producing ${ }^{207} \mathrm{~Pb}$ ), and ${ }^{238} \mathrm{U}$ (producing ${ }^{206} \mathrm{~Pb}$ ). Table 1 provides the production mechanism, the half-lives, and the isotopic abundances for the nuclides discussed in this paper.

Parent nuclides can be fractionated from the isotopes of the daughter elements by natural processes at or near the Earth's surface. For example, Rb can be separated from $\mathrm{Sr}$ by a number of processes, including crystal formation (magmatic as well as aqueous precipitation), differential mobility during weathering reactions, and differential adsorption to solids for $\mathrm{Sr}$ and $\mathrm{Rb}$ cations in solution. In systems with high $\mathrm{Rb} / \mathrm{Sr}$ ratios, time-integrated decay of ${ }^{87} \mathrm{Rb}$ to ${ }^{87} \mathrm{Sr}$ will produce high ${ }^{87} \mathrm{Sr} /{ }^{86} \mathrm{Sr}$ ratios ( ${ }^{86} \mathrm{Sr}$ is not radiogenic). Systems with low $\mathrm{Rb} / \mathrm{Sr}$ ratios will produce low ${ }^{87} \mathrm{Sr} / 86 \mathrm{Sr}$ ratios. In the same way, systems with high $\mathrm{Sm} / \mathrm{Nd}$ ratios produce high ${ }^{143} \mathrm{Nd} /{ }^{144} \mathrm{Nd}$ ratios, systems with high $\mathrm{U} / \mathrm{Pb}$ ratios produce high $206 \mathrm{~Pb} / 204 \mathrm{~Pb}$ ratios, and systems with high $\mathrm{Th} / \mathrm{Pb}$ ratios produce high ${ }^{208} \mathrm{~Pb} / 204 \mathrm{~Pb}$ ratios. Such radiogenic isotopic variations are ubiquitous in nature and can be used to great advantage in hydrologic studies.

Water masses originating in different lithologies will likely have different $\mathrm{Sr}$ isotopic compositions due to isotopic differences in the lithologies themselves. The isotopic compositions of dissolved $\mathrm{Sr}$ have been used to distinguish hydrostratigraphic units (Stueber et al., 1987; 1993), to delineate groundwater flow paths and recharge locations (Collerson et al., 1988; Peterman et al., 1992), to recognize instances of groundwater mixing and distinguish the mixing endmembers (Stueber et al., 1987; Lowry et al., 1988), to recognize paleohydrologic flow systems (Stueber et al., 1993), to track groundwater chemical evolution (McNutt, 1987; Connolly et al., 1990), to determine the genesis of crude oils and oil-field brines (Starinsky et al., 1983a; Nakano et al., 1989), and to assess petroleum reservoir connectivity (Smalley et al., 1992). Although the studies cited are regional in scope, the principles upon which they are based can also be useful on the catchment scale, as will be discussed below.

Although many of the uses of lithogenic nuclides in hydrology, such as those just mentioned, are based on differences in whole-rock isotopic compositions, perhaps the most useful characteristic of lithogenic nuclides is that there are significant differences in isotopic compositions between minerals within the same rock or soil. This is because the ratios between the parent element (e.g., $\mathrm{Rb}$ ) and the daughter element (e.g., $\mathrm{Sr}$ ) vary between the mineral phases within the same rock or soil. Through geologic time, therefore, the relative abundances of the daughter 
nuclides will be different in each mineral phase. Figures 1 and 2 provide examples of resulting isotopic variations. In the example of $\mathrm{Sr}$ in a typical granitic rock (Figure 1), biotite will have a $\mathrm{Rb} / \mathrm{Sr}$ ratio of about 83 , alkali feldspar about 1.25 , hornblende about 0.30 ; and plagioclase about 0.03 . When the granite formed, the $\mathrm{Sr}$ isotopic compositions would have been the same in all of the mineral phases; $\mathbf{S r}$ isotopes do not fractionate by magmatic processes and would have been homogenized within the magma. After formation of the rock, the $\mathrm{Sr}$ isotopic compositions of the mineral phases would begin to change at a rate dependent on the $\mathrm{Rb} / \mathrm{Sr}$ ratio of the mineral. For a granite that formed $50 \mathrm{Ma}$ ago (Eocene) and began with a $\delta^{87} \mathrm{Sr}$ value of -6.63 throughout the rock, the $\delta^{87} \mathrm{Sr}$ values in the mineral today would be: +234.25 (biotite), -3.01 (alkali feldspar), -5.76 (hornblende), and -6.55 (plagioclase). Had this same granite instead formed $500 \mathrm{Ma}$ ago (Ordovician), the $\delta^{87} \mathrm{Sr}$ values today would be: +2411 (biotite), +29.64 (alkali feldspar), +2.08 (hornblende), and -5.81 (plagioclase). The $\delta^{87} \mathrm{Sr}$ value present in groundwater associated with these granites could be very different depending on the mineral source of the $\mathrm{Sr}$ in solution. The utility of this fact for catchment hydrology is that not all mineral phases within any rock or soil type weather at the same rate. Some mineral phases contribute solutes early in the weathering process while others persist and contribute solutes very late in the process.

The Mineral Weathering Sequence and Resulting Isotopic Variations. It has long been noted that the susceptibility of a mineral phase to weathering is related to its position in Bowen's Reaction Series (Goldich, 1938). The Reaction Series was devised by Bowen (1928) to represent the approximate crystallization sequence of minerals forming from an evolving magma, beginning with a high-temperature basic magma and resulting in a low-temperature silicic magma (Figure 3). Two crystallization series are actually present: the continuous series composed of the plagioclase compositions (anorthite to albite), and the discontinuous series composed of minerals that have increasingly more complex crystal structures (olivine, a nesosilicate, to biotite, a phyllosilicate). The final steps of the Reaction Series involve alkali feldspar and quartz. During the weathering process; those mineral phases that form early in the Reaction Series, e.g., olivine and anorthite, weather more readily than those phases that form late in the Series, e.g., quartz. The discontinuous series ("mafic" minerals) weathers more readily than the continuous series (feldspars). It is commonly observed that during the weathering 
of feldspars, the plagioclase feldspars are much less resistant than the alkali feldspars. For relatively pure sandstones that lack easily weathered minerals, the number of weathering cycles experienced by the minerals (the "maturity" of the rock) is commonly judged by the ratio of alkali feldspar to quartz (Pettijohn, 1975, p. 212). Thus, Bowen's Reaction Series can also be regarded as a weathering reaction scries. A more eloquent treatment of the weathering sequence as it relates to Bowen's Reaction Series is given by Curtis (1976), where it is demonstrated that the free-energy changes of the weathering reactions are more negative (more thermodynamically favored) for the mineral phases early in the Series as opposed to those late in the Series.

For the granitic rock depicted in Figure 1, the initial mineral phases to react during weathering will be those of the discontinuous series, hornblende and biotite. For any significant age of the rock, the hornblende $\delta^{87} \mathrm{Sr}$ value will be similar to the whole rock value, but the biotite values will be extremely high (Figure 1 ). The initial $\mathrm{Sr}$ isotopic compositions released during weathering will be dominated by biotite compositions. As weathering proceeds, the biotite will begin to disappear and the weathering of plagioclase will begin to dominate. High degrees of weathering, as might occur in a regolith soil derived from the granite, will release Sr with the isotopic composition of the alkali feldspar. Through the weathering cycle the isotopic composition of the released $\mathrm{Sr}$ will change from very high values (from biotite) to low values (from plagioclase) to moderate values (from alkali feldspar). This progression can be regarded not only as a temporal sequence, but also as a sequence occurring in soil column. The isotopic compositions in the upper, most weathered portion of the column will be different from those in lower portions of the column. Potential uses of this isotope "stratigraphy" in catchment hydrology will be discussed below.

Origin of Isotopic Variations: Uranium Isotopes and Alpha Recoil. Uranium-238 undergoes radioactive decay to produce ${ }^{234} \mathrm{U}$ through two very short-lived intermediate decays $\left({ }^{234} \mathrm{Th}\right.$ with a half-life of about 24 days, and ${ }^{234} \mathrm{~Pa}$ with a halflife of about one minute). Uranium-234 is also radioactive and decays to $230 \mathrm{Th}$ (the half-life of ${ }^{234} \mathrm{U}$ is about 245,000 years). Over geologic time, an equilibrium is established between the production of ${ }^{234} \mathrm{U}$ from ${ }^{238} \mathrm{U}$ and the decay of ${ }^{234} \mathrm{U}$. This equilibrium is termed "secular equilibrium". The uranium isotopes in any closed system will be in secular equilibrium after about five half-lives of ${ }^{234} \mathrm{U}$ (about 1.25 
million years). The equilibrium is generally discussed in terms of the activity ratio between the isotopes. The "activity" of a radionuclide is the average number of atoms undergoing radioactive decay per unit time (for example, 10 decays/minute). For two nuclides to be in secular equilibrium, the ratio of their activities must equal one. That is, for a given amount of time, as many atoms are being produced as are decaying.

It has long been observed that the two uranium isotopes are seldom in secular equilibrium in natural waters (Cherdyntsev et al., 1955). The activity ratio of ${ }^{234} \mathrm{U}$ to ${ }^{238} \mathrm{U}$ is generally greater than one, often substantially greater. The cause of this is not entirely clear, although it is very likely a function of the alpha decay process that produces ${ }^{234} \mathrm{Th}$. The alpha particle is ejected from the nucleus with sufficient energy that the recoil of the atom ( $72 \mathrm{MeV}$ recoil energy) causes damage to the crystal lattice, leaving a path or track along its trajectory. The length of the typical track will vary with the density of the enclosing material, but has been estimated to be between $10 \mathrm{~nm}$ (Huang et al., 1967) and $55 \mathrm{~nm}$ (Kigoshi, 1971), perhaps typically about $30 \mathrm{~nm}$ (Andrews et al., 1982). The damage to the crystal provides an area of weakness from which the atom can be more easily leached by groundwater (Fleischer, 1988). This may account for some of the increase in ${ }^{234} \mathrm{U}$ relative to ${ }^{238} \mathrm{U}$ in the water, particularly in newly-recharged water with low uranium concentrations (Andrews and Kay, 1978). Another important mechanism for increasing the activity ratio is the recoil ejection of ${ }^{234} \mathrm{Th}$ from the crystal directly into the water. Although this would require the decaying ${ }^{238} \mathrm{U}$ atoms to be within $10-55 \mathrm{~nm}$ of the edge of the crystal, it can be easily demonstrated that typical uranium concentrations in rocks would provide sufficient ${ }^{238} \mathrm{U}$ atoms at this depth to lead to the observed disequilibrium values (Fleischer, 1982; 1983; Andrews et al., 1982).

Another important consideration for ${ }^{234} \mathrm{U} / 238 \mathrm{U}$ disequilibrium is the redox condition of the groundwater. Uranium is moderately soluble under oxidizing conditions, existing in the $\mathrm{UO}_{2}+2$ state (Langmuir, 1978). Under reducing conditions uranium is highly insoluble, and will tend not to enter into groundwater through leaching or dissolution processes. Enhanced leaching of $234 \mathrm{U}$ from damaged sites will not be a mechanism for increasing the ${ }^{234} \mathrm{U} / 238 \mathrm{U}$ ratio in the water. Some ${ }^{234} U$ will still enter by direct recoil ejection, and insofar as any uranium remains in solution, the ${ }^{234} \mathrm{U} / 238 \mathrm{U}$ ratio of this uranium will tend to increase by this process (Andrews et al., 1982). However, the decay of ${ }^{234} \mathrm{U}$ will 
begin to dominate and the activity ratios in the water will gradually decrease as a function of time (Andrews et al., 1982). Under oxidizing conditions, therefore, the ${ }^{234} \mathrm{U} / 238 \mathrm{U}$ ratios in groundwater would be expected to increase with time, whereas under reducing conditions the ratio would be expected to decrease with time. The dependence of this decrease on the half-life decay of $234 \mathrm{U}$ has made the uranium system attractive for groundwater dating purposes. However, the many geochemical complications in the behavior of uranium has often led to unsatisfactory results (Latham and Schwarcz, 1989). It nonetheless appears that if the local hydrogeology and the behavior of uranium within the system are well enaugh characterized, uranium activity ratios can be used to place constraints on the age of the groundwater (Andrews and Kay, 1983; Frohlich and Gellerman, 1987; Ivanovich et al., 1991).

The uranium activity ratios have been used for a wide variety of purposes related to characterization of groundwater systems. They have been used to differentiate groundwater bodies and identify locations of interconnectivity (Guttman and Kronfeld, 1982; Ivanovich and Alexander, 1987), to place constraints on groundwater flow paths and flow rates (Kronfeld et al., 1979), to assess groundwwater mixing, endmember compositions, and mixing volumes (Ivanovich and Alexander, 1987; Banner et al., 1990), to identify instances of pore-water mixing (Andrews and Kay, 1982; Cuttell et al., 1986), to quantitatively assess water-rock chemical interaction (Andrews and Kay, 1983; Banner et al., 1990), to examine variations in mobility of actinides in natural environments (Krishnaswami et al., 1982; Latham and Schwarcz, 1989; Guthrie, 1991), to determine the geochemistry of uranium in particular geohydrologic environments (Kraemer and Kharaka, 1986), and to aid in prospecting for uranium mineral deposits (Osmond et al., 1983).

Origin of Isotopic Variations: Cosmogenic Nuclides. In addition to changing the configuration of a nucleus by means of radioactive decay, atoms can undergo similar changes due to bombardment by incoming nuclear particles (principally protons, neutrons, and alpha particles). The bombardment causes a change in the nuclear and electronic configuration of the atom, producing a nuclide of another variety. The major source of the nuclear particles is cosmic radiation, most of which originates in the sun, although a significant amount, possessing higher energies, also comes from outside of the solar system. The cosmic radiation particles are primarily protons and alpha particles, but their interactions with atoms in the 
Earth's atmosphere produce neutrons which then bombard other atoms. Bombardment of atoms in the Earth's atmosphere creates several nuclides of importance in hydrology. These are termed "atmospheric" or "cosmogenic" nuclides, and include ${ }^{3} \mathrm{H}$ (tritium), ${ }^{10} \mathrm{Be}$ and ${ }^{14} \mathrm{C}$ (produced primarily from oxygen and nitrogen), ${ }^{32} \mathrm{Si}$ and ${ }^{36} \mathrm{Cl}$ (produced primarily from argon), ${ }^{41} \mathrm{Ca}$ and ${ }^{81} \mathrm{Kr}$ (produced primarily from krypton) and ${ }^{129} \mathrm{I}$ (produced primarily from xenon). Significant cosmogenic production of ${ }^{10} \mathrm{Be},{ }^{36} \mathrm{Cl}$, and ${ }^{41} \mathrm{Ca}$ also occurs on and near the Earth's surface in rock and soil (the primary target for ${ }^{41} \mathrm{Ca}$ here is ${ }^{40} \mathrm{Ca}$ ). Surficial rock and soil production of the other nuclides mentioned is very minor compared to other means of production. Table 1 provides the production mechanism, the half-lives, and typical isotopic abundances for the cosmogenic nuclides of importance to hydrology and discussed in this paper.

Deep subsurface bombardment of atoms by nuclear particles also occurs. Here the source of the particles (primarily neutrons) is the decay of radioactive elements, principally $U$ and $T h$ decay-series nuclides. This mode of production is termed "insitu" lithogenic production. For hydrologic considerations, in-situ production is important for three nuclides: ${ }^{36} \mathrm{Cl},{ }^{39} \mathrm{Ar}$, and ${ }^{129} \mathrm{I}$. The in-situ production of ${ }^{36} \mathrm{Cl}$ is due primarily to neutron activation of ${ }^{35} \mathrm{Cl}$, the more abundant of the two stable $\mathrm{Cl}$ isotopes. The in-situ production of ${ }^{39} \mathrm{Ar}$ is due primarily to neutron activation of ${ }^{39} \mathrm{~K}$ (which makes up about $93 \%$ of all potassium), and in high- $\mathrm{K}$ environments, production could be quite significant. Iodine-129, while produced through neutroninduced fission of $235 \mathrm{U}$, is primarily produced in the subsurface through spontaneous fission of $238 \mathrm{U}$.

A third setting for nuclear particle bombardment is man-induced thermonuclear events, the most significant for modern hydrologic studies being the atmospheric nuclear weapons testing of the 1950's and 1960's. The "thermonuclear" hydrologic nuclides include ${ }^{3} \mathrm{H}$ (tritium), ${ }^{14} \mathrm{C},{ }^{36} \mathrm{Cl},{ }^{85} \mathrm{Kr}$, and ${ }^{129} \mathrm{I}$. These nuclides were dispersed worldwide and although they are present in very small quantities, are detectable in all modern environments (e.g., groundwater recharged during the past 40 years). The atmospheric levels of tritium, ${ }^{14} \mathrm{C},{ }^{36} \mathrm{Cl}$, and ${ }^{129} \mathrm{I}$ have today returned to pre-bomb levels. Recharged water is no longer being fingerprinted by these bomb-pulse nuclides. However, ${ }^{85} \mathrm{Kr}$ has continued to increase in the atmosphere, presumably as the result of outgassing related to the production of nuclear power. 
The attractiveness of chlorine in hydrologic studies is that it is highly soluble, exists in nature as a conservative non-sorbing anion, does not participate in redox reactions, and has some quickly identifiable sources (e.g., seawater). The abundance of ${ }^{36} \mathrm{Cl}$ is usually reported as the atomic ratio of ${ }^{36} \mathrm{Cl}$ to total chloride in the sample. The ratio is always quite small, typical values present in nature range from $10^{-15}$ to $10^{-11}$. When observed in groundwater, the higher values usually indicate input from thermonuclear ${ }^{36} \mathrm{Cl}$. The cosmogenic ratio ${ }^{36} \mathrm{Cl} / \mathrm{Cl}$ entering groundwater through precipitation will vary as a function of distance from the oceans. The added chlorine input from the ocean, which has a very low ${ }^{36} \mathrm{Cl} / \mathrm{Cl}$ ratio, leads to low ratios along the coasts (20-80 $\times 10^{-15}$ ), while North American midcontinent values will exceed $500 \times 10^{-15}$ (Bentley et al., 1986a). The half-life of ${ }^{36} \mathrm{Cl}$ is approximately 300,000 years, and attempts have been made to date groundwater in confined aquifers by the ${ }^{36} \mathrm{Cl} / \mathrm{Cl}$ ratio (Bentley et al., 1986b; Phillips et al., 1986). Beside the difficult problem of determining the starting $\left(t_{\varnothing}\right){ }^{36} \mathrm{Cl} / \mathrm{Cl}$ ratio (Andrews and Fontes, 1993), the subsurface addition of chloride to the water by either chemical reactions with rock, ion filtration (Phillips et al., 1986), or mixing with higher chloride waters makes ${ }^{36} \mathrm{Cl}$ age dating very difficult. The presence in a groundwater sample of thermonuclear ${ }^{36} \mathrm{Cl}$, however, clearly indicates a very young age (Fabryka-Martin et al., 1991; Caffee et al., 1992; Hudson et al., 1993; Nimz et al., 1993).

Another problem encountered in attempting to date very old groundwater water that should have very low ${ }^{36} \mathrm{Cl} / \mathrm{Cl}$ values - is the in-situ production of ${ }^{36} \mathrm{Cl}$. Over geologic time (in fact, about 5 half-lives of ${ }^{36} \mathrm{Cl}$, or 1.5 million years), an equilibrium will be established between the subsurface production of ${ }^{36} \mathrm{Cl}$ and its decay (similar to the secular equilibrium of $U$ isotopes; Andrews et al., 1986). The equilibrium ${ }^{36} \mathrm{Cl} / \mathrm{Cl}$ value will depend on the rate of production of ${ }^{36} \mathrm{Cl}$, which is a function of the neutron flux in the rock matrix. Since the neutrons originate primarily from the radioactive decay of $U$ - and Th-series nuclides, the subsurface production of ${ }^{36} \mathrm{Cl}$ is dependent on the rock $U$ and $T h$ concentrations. As Table 2 indicates, basalts, sandstones, and limestones typically have very low $U$ contents, while silicic granitic rocks and shales have higher concentrations. Equilibrium ${ }^{36} \mathrm{Cl} / \mathrm{Cl}$ values in sandstones and limestones should be on the order of $10-20 \times 10^{-15}$, whereas granitic rocks and shales will have values from about 30-90 $\times 10^{-15}$ (Lehmann and Loosli, 1991). It is clear that with natural input values in precipitation that can range from perhaps $500 \times 10^{-15}$ down to $20^{\times} 10^{-15}$, in-situ 
${ }^{36} \mathrm{Cl}$ can have significant affects on the subsurface ${ }^{36} \mathrm{Cl} / \mathrm{Cl}$ ratio, and can make age dating very difficult. However, the difference in equilibrium values between various rock types, as well as the much higher precipitation input values, makes ${ }^{36} \mathrm{Cl}$ become a valuable groundwater tracer (Nimz et al., 1993).

Cosmogenic, thermonuclear, and in-situ lithogenic ${ }^{36} \mathrm{Cl}$ has been used in a variety of hydrologic studies since the early 1980's. Chlorine-36 has been used to discriminate groundwater bodies and assess degrees of mixing (Phillips et al., 1984; Andrews et al., 1986; Dowgiallo et al., 1990; Torgerson et al., 1991), to determine groundwater flow paths (Andrews et al., 1986; Bentley et al, 1986a, Beasley et al., 1993), to place constraints on groundwater age (Bentley et al., 1986b; Phillips et al., 1986; Fabryka-Martin et al., 1991; Torgerson et al., 1991; Fehn et al., 1992), to identify very young - bomb-pulse - groundwater (Bentley et al., 1982; Haberstock et al., 1986; Purdy et al., 1987), to determine instances of vertical recharge along a flow path (Purdy et al., 1987), to identify sources of chlorinity and salinity (Andrews et al., 1986; 1989; Paul et al., 1986; Phillips et al., 1986), to identify sources of salt deposits (Margaritz et al., 1986; Paul et al., 1986), to estimate infiltration amounts and depths in arid regions (Norris et al., 1987; Phillips et al, 1988; Cecil et al., 1992), to make quantitative estimates of evaporation and evapotranspiration (Paul et al., 1986; Margaritz et al., 1990), and to investigate paleohydrologic conditions (Jannik et al., 1991; Torgerson et al., 1991).

Iodine-129 is in many ways similar to ${ }^{36} \mathrm{Cl}$. It is a soluble halogen that is fairly non-reactive, generally exists as a non-sorbing anion in groundwater, and is produced in cosmogenic, thermonuclear, and in-situ neutron-induced reactions. It is usually reported in groundwater studies as the atomic ratio of ${ }^{129} \mathrm{I}$ to total I (which in nature is virtually all ${ }^{127} \mathrm{I}$ ). As with ${ }^{36} \mathrm{Cl} / \mathrm{Cl}, 129 \mathrm{I} / \mathrm{I}$ ratios in nature are quite small, $10^{-14}$ to $10^{-10}$ (peak thermonuclear ${ }^{129} \mathrm{I} / \mathrm{I}$ during the 1960 's and 1970 's reached $\sim 10^{-7}$; Fabryka-Martin et al., 1989). Iodine-129 differs from ${ }^{36} \mathrm{Cl}$ in that its half-life is very long (1.6 million years), it is highly biophilic, and presents more problems analytically than ${ }^{36} \mathrm{Cl}$ (Roman and Fabryka-Martin, 1988; Fehn et al., 1987). The latter problem, perhaps more than anything, has led to far fewer ${ }^{129} \mathrm{I}$ studies than ${ }^{36} \mathrm{Cl}$ studies. It also differs from ${ }^{36} \mathrm{Cl}$ in the interesting way that because of its long half-life, the ${ }^{129} \mathrm{I} / \mathrm{I}$ ratio in nature is quite homogeneous (Fabryka-Martin et al., 1985). Thermonuclear ${ }^{129}$ I has disrupted this homogeneity somewhat, particularly near nuclear power plants and production facilities, but for Earth-surface hydrogeological processes (such as recharge) that are older than or 
geographically removed from this activity, the initial or input ratio will be approximately 10-12 (Fabryka-Martin et al., 1989). A potential value to this uniform input ratio is that age dating should be less complex than for ${ }^{36} \mathrm{Cl}$. Unfortunately, there are competing factors that make ${ }^{129} \mathrm{I}$ dating more complicated than one would hope. The long half-life makes ${ }^{129} \mathrm{I}$ appropriate for dating old systems only; old groundwaters have obviously experienced a wider variety of hydrogeologic environments and phenomenon than have younger waters. Each of these can add complications to the interpretation of ${ }^{129} \mathrm{I}$ data. Also, in-situ ${ }^{129} \mathrm{I}$ production can be very significant in a number of geologic environments (for example, ${ }^{129} \mathrm{I} / 1$ equilibrium values in granites will be $\sim 5 \times 10^{-12}$; Fabryka-Martin et al., 1985). Therefore, a careful understanding of the hydrogeology of the groundwater system will always be necessary. It is possible that except in special environments unusually suited to ${ }^{129} \mathrm{I}$ dating (e.g., crude oils; Fabryka-Martin et al., 1985; Moran et al, 1993), the use of ${ }^{129} \mathrm{I}$ may be mainly limited to hydrologic tracing and mixing assessments. The increased analytical difficulty of ${ }^{129}$ I makes ${ }^{36} \mathrm{Cl}$ the preferable nuclide for bomb-pulse dating; this fact, combined with the extremely long ${ }^{129} \mathrm{I}$ half-life, makes ${ }^{129} \mathrm{I}$ less useful than $36 \mathrm{Cl}$ for the characterization of shallow, young groundwater systems.

There have been several hydrologic studies that have made use of ${ }^{129} \mathrm{I}$. It has been demonstrated to have value in placing constraints on groundwater age (Fabryka-Martin et al., 1985; 1989; Fehn et al., 1992; Moran et al., 1993), determining groundwater migration paths (Fabryka-Martin et al., 1988), identifying sources of salinity in groundwater and sources of salts in evaporite deposits (Fabryka-Martin et al., 1985; Fabryka-Martin et al., 1991; Fehn et al., 1992), estimating weathering rates and the behavior of iodine and uranium during weathering (Fabryka-Martin et al., 1988), and identifying the source geologic formation for hydrocarbons (Fabryka-Martin et al., 1985). These studies indicate the utility of ${ }^{129} \mathrm{I}$ in hydrologic studies. Despite the analytical difficulty and the care required for data interpretation, the promise demonstrated by these studies, along with the constancy in the atmospheric input ratio, the significant isotopic differences in existing in-situ reservoirs, and the hydrophilic and biophilic behaviors of iodine, the hydrologic uses of ${ }^{129} \mathrm{I}$ appear to be largely untapped.

This section has discussed the general hydrologic applications of lithogenic, cosmogenic, and related thermonuclear elements, and the processes that affect their 
isotopic compositions. The following section discusses the potential utility of these elements and their isotopes in catchment-scale hydrologic systems.

\section{Lithogenic and Cosmogenic Nuclides: Uses in Catchment Hydrology}

Relatively few catchment-scale hydrologic studies have as yet been published that employ lithogenic or cosmogenic nuclides (other than ${ }^{3} \mathrm{H}$ and ${ }^{14} \mathrm{C}$ ). Those that have been published show interesting and valuable results, and many of these will be reviewed in the following. However, this section is intended to present the catchment system from the standpoint of the ways in which lithogenic and cosmogenic nuclides can be useful, rather than from a standpoint of a literaturereview. In addition, many of the published studies cited above, although not on a catchment scale, give clear indications of the utility of lithogenic and cosmogenic nuclides for any hydrologic scale.

The processes occurring in a catchment system have traditionally been divided into a number of discrete sub-processes, each of which have measurable parameters that cap be used to characterize catchment hydrology (Figure 4). The sub-processes together represent the possible paths of water as it is input into the system (Precipitation, Dry Deposition, Throughfall, Stemflow), makes its way through the system (Overland Flow, Interflow, Throughflow, Subsurface Flow), and ultimately leaves the system (Evaporation, Transpiration, Leakage, Steamflow). This subdivision of processes will be used in the following discussion of lithogenic and cosmogenic nuclides in catchment hydrology.

Input: Precipitation, Dry Deposition, and Throughfall. A significant quantity of solutes are imported into a catchment basin through aerosols, rain, and snow. The amount imported can be a surprisingly high amount of the total elemental budget for a catchment. For example, Aberg et al. (1989) reported a rainfall $\mathrm{Sr}$ concentrations of $1.8 \mu \mathrm{g} / \mathrm{L}$ in an area that received $900 \mathrm{~mm}$ of rain per year. This totals to $16.2 \mathrm{~g} / \mathrm{ha} / \mathrm{yr}$ of $\mathrm{Sr}$. If the chemical denudation rate of this area is the estimated average rate for North America, $3.3 \times 10^{5} \mathrm{~g} / \mathrm{ha} / \mathrm{yr}$ (Garrels and MacKenzie, 1971), and the $\mathrm{Sr}$ concentration of the removed rock is the average for granitic rocks, $250 \mu \mathrm{g} / \mathrm{g}$ (Table 2), then the amount of Sr denuded from the basin would be $82.5 \mathrm{~g} / \mathrm{ha} / \mathrm{yr}$. The incoming $\mathrm{Sr}$ from precipitation makes up $16.4 \%$ of all of 
the "free" Sr within the drainage area per year. Strontium added to the basin by aerosols (dry deposition) would increase the input amounts, possibly substantially. The use of $\mathrm{Sr}$ isotopes for assessing hydrologic processes must take into account the amount of $\mathrm{Sr}$ input into the system under investigation, and the isotopic composition of that Sr. This would be the case for any solute present in meaningful quantities in precipitation and dry deposition, which excludes very few lithogenic nuclides. Notably, there would be very little Th input into the system relative to other lithogenic elements (Table 2); this suggests that the rainfall fractionation of Th from other lithogenics might be useful in elucidating processes that are closely tied with new rainfall, such as stormflow hydrograph separation.

The importance of aerosol components was demonstrated by Starinsky et al. (1983b). They sampled groundwater from wells and springs in a western coastal are of the Sinai peninsula. The $\mathrm{Ca} / \mathrm{Sr}$ ratio of the water was much too low for the $\mathrm{Sr}$ to have been derived for the alluvial aquifer material. The isotopic composition of the $\mathrm{Sr}\left(\delta^{87} \mathrm{Sr} \approx-0.28\right)$ was too dissimilar to the bedrock in the region $\left(\delta^{87} \mathrm{Sr} \approx+15.2\right)$ for it to have been the $\mathrm{Sr}$ source. The closest appropriate source for the $\mathrm{Sr}$ were aragonite beach sands and sabkha deposits of the Sinai coastal plain, about ${ }^{3} 0$ kilometers away. These deposits have the isotopic composition of the ocean $\left(\delta^{87} \mathrm{Sr}=\right.$ 0.0 ), which is similar to the $\mathrm{Sr}$ in the groundwater samples. Starinsky et al. (1983b) concluded that the $\mathrm{Sr}$ in the groundwater reflected deposition of aerosols from the coast.

The isotopic composition of $\mathrm{Sr}$ has also been used to determine the origin of pedogenic carbonates in desert soils (caliche). There has long been a question of whether the $\mathrm{Ca}$ in caliche is derived from in-situ weathering or aeolian input. Because of the close similarity in geochemical behavior between $\mathrm{Ca}$ and $\mathrm{Sr}$, this study strongly suggests that the $\mathrm{Ca}$ in the desert carbonates did not originate by insitu weathering, but was imported into the soils. Because of the close similarity in geochemical behavior between $\mathrm{Ca}$ and $\mathrm{Sr}$, the behavior of $\mathrm{Sr}$ can be used as an analogue for Ca. Capo and Chadwick (1993) examined the $\mathrm{Sr}$ isotopic composition of rain, dust, and acetic acid leachates from the A, B and petrocalcic horizons from a desert soil in New Mexico. The weak acid leach would dissolve carbonate material but leave silicate minerals as a "residue". The soil acetic acid leachate had ${ }^{87} \mathrm{Sr}$ values of about -0.28 , which is very similar to local rain and dust values of about -0.42. The silicate fraction on the other hand had $\delta^{87} \mathrm{Sr}$ values that ranged from +5.64 to +11.42 . This strongly indicates that the $\mathrm{Sr}$ originated outside of the system 
and was input through rain and dust. It is not unreasonable, therefore, to conclude that by analogy much of the $\mathrm{Ca}$ in the caliche is also from external sources.

Aberg et al. (1989) conducted an interesting study of the solute relationships of rainfall, throughfall, and surface flow using $\mathrm{Sr}$ isotopic compositions. Rainfall compositions during a two year span of their study ranged from $\delta^{87} \mathrm{Sr}=+2.82$ to + 13.18. Water collected from throughfall ranged from $\delta^{87} \mathrm{Sr}=+26.79$ to +40.75 , while water collected on the ground surface had a value of +35.82 . A peat sample on the ground surface had $\delta^{87} \mathrm{Sr}=+16.67$. All of these values are in sharp contrast to bedrock $\delta^{87} \mathrm{Sr}$, which was +296.81 . The $\mathrm{Sr}$ isotopic composition of the rainwater from this drainage was changed significantly through interaction with the foliage (birch and spruce trees). The concentration of Sr changed from less than $3.5 \mu \mathrm{g} / \mathrm{L}$ (rain) to $46-77 \mu \mathrm{g} / \mathrm{L}$ (throughfall). The throughfall concentrations are significant relative to groundwater within the drainage. A sample of deep groundwater from the bedrock contained $161 \mu \mathrm{g} / \mathrm{L}$, suggesting that the isotopic contribution from throughfall could be as much as $48 \%(77 / 161)$ of the $\mathrm{Sr}$ isotope budget.

Similar findings have been reported by Graustein and Armstrong (1980). They were able to separate the throughfall from the broadleaf trees (aspen) from the fir trees (spruce) and found the aspen throughfall to have higher $\delta^{87} \mathrm{Sr}(+1.97$ for spruce and +10.86 for aspen; rainfall was measured $\delta^{87} \mathrm{Sr}=+1.13$ to 1.69 ). Analyses from fiber material from the trees themselves produced a similar difference: spruce bole had a $\delta^{87} \mathrm{Sr}$ value of +6.91 , aspen bole had a value of +14.81 . Graustein and Armstrong felt that the difference between broadleaf and fir trees implied that the isotopic difference between rainwater and throughfall was largely due to aeolian input. Dust could cling to the aspen leaves better than the spruce needles, and eventually became part of the plant fiber.

Although atmospheric input of lithogenic nuclides into a hydrologic system is often ignored in isotopic studies, it should not be overlooked in catchment hydrology where surface water becomes an important consideration. The solute input is a significant percentage of the total solute budget for surface and near-surface waters, and the isotopic compositions of the incoming material are likely to be very different from those present in the catchment.

The use of cosmogenic nuclides in catchment hydrology of course relies on the external input of solutes into the system. Chlorine (incorporating ${ }^{36} \mathrm{Cl}$ ) in North American rainwater has been measured to vary from about $8 \mathrm{mg} / \mathrm{L}$ along the coasts to about $0.1 \mathrm{mg} / \mathrm{L}$ inland (Junge and Werby, 1958). Like rainfall $\mathrm{Sr}$, this is a 
significant input of $\mathrm{Cl}$ per year. However, while the atmospheric input of ${ }^{36} \mathrm{Cl}$ can be used as a groundwater tracer and for age dating in large regional groundwater systems that contain ${ }^{36} \mathrm{Cl}$ old enough to show effects of radioactive decay (FabrykaMartin et al., 1991), its use on a catchment scale with young water is limited. Thermonuclear ${ }^{36} \mathrm{Cl}$ on the other hand can be very useful on the catchment scale to discriminate water recharged during the 1950's through the 1980's from older water. The use of ${ }^{3} \mathrm{H}$ for this purpose is commonplace in hydrologic studies. However, ${ }^{3} \mathrm{H}$ has a half-life of only 12.3 years; the bomb-pulse ${ }^{3} \mathrm{H}$ in water today will decay to insignificant amounts by about the year 2020. Because the half-life of ${ }^{36} \mathrm{Cl}$ is about 300,000 years, the bomb-pulse will still be present when the ${ }^{3} \mathrm{H}$ pulse is gone. In the $1.7 \mathrm{~km}^{2}$ Wawona catchment in Yosemite National Park, ${ }^{36} \mathrm{Cl}$ has been used to differentiate young water from a much older water mass that exists only about 100 meters beneath the surface (Caffee et al., 1992; Nimz et al., 1993). Figure 5 shows the ${ }^{36} \mathrm{Cl}$ values from Wawona relative to well depth. Most of the water samples have ${ }^{36} \mathrm{Cl} / \mathrm{Cl}$ ratios of $1000 \times 10^{-15}$ or greater. Deep waters uniformly have ${ }^{36} \mathrm{Cl} / \mathrm{Cl}$ ratios under $30 \times 10^{-15}$. The few samples with intermediate values may represent water recharged prior to 1950 , or may represent mixing of the deep older water with the recently recharged water. The existence of older water at such shallow depths, the sharp delineation between the two water masses, and the relative lack of samples that suggest mixing are surprising features of this catchment that have been made clear through the use of thermonuclear ${ }^{36} \mathrm{Cl}$. As demonstrated for lithogenic nuclides, the input of cosmogenic nuclides into catchment systems is significant, and at least for the thermonuclear variety can be valuable in understanding catchment hydrology.

The Shallow System: Hydrograph Separation, Weathering, and Arid-Region Infiltration. Many studies have used solute mass balance in attempts to better understand the components of hydrograph separation (DeWalle et al., 1988; Robson and Neal, 1990; Wels et al., 1991). This suggests that solute isotopic compositions may be useful as well. The isotopic composition of oxygen and hydrogen have been very useful in shaping modern perspectives on stormflow generation (Pearce et al., 1986; Sklash et al., 1986).

The studies discussed above by Aberg et al. (1989) and Graustein and Armstrong (1980) indicate that there can be significant isotopic differences between rain, surface flow, and groundwater flow. However, Miller and Drever (1977b) 
noted that surface flow tends to quickly rinse the system and overland flow becomes more dilute (more like rainwater) with time. Although this would blur the distinction between rainfall and surface flow, it would tend to emphasize distinctions between later overland flow and soil water (throughflow) or groundwater. This could be extremely valuable to hydropraph separation studies. Aberg et al. (1989) also examined the $\mathrm{Sr}$ isotopic compositions of exchangable $\mathrm{Sr}$ within the soil column (from weak-acid leachates) and soil water (from lysimeters). The leachate/water $\delta^{87} \mathrm{Sr}$ values $(+39.3$ to +45.91 ; decreasing downward in the soil column) were considerably higher than either the precipitation values $(<+13.18)$, or the value obtained for surface flow (+35.82). Groundwater sampled from a depth of one meter had a $\delta^{87} \mathrm{Sr}$ value of +36.02 , and deeper groundwater (depth unspecified) had a value of +102.51 . The differences in these isotopic compositions are more than sufficient to lend themselves to hydrograph separation analysis.

The variations in isotopic compositions within the soil column are due to variations in the weathering-residual mineralogy within the column (see the followup study to that of Aberg et al. (1989): Wickman and Jacks, 1992). The higher isotopic values in the more shallow zone were attributed to the predominance of alkali feldspar weathering, while at depth plagioclase feldspar still predominated. Plagioclase had already been depleted in the most shallow zones. This is consistent with the expected isotopic ratios in each mineral (Figure 1). Analogous changes in exchangable $\mathrm{Sr}$ isotopic composition were observed in a sequence of soils with variable ages in the Sierra Nevada foothills (White et al., 1992). The youngest soils $\left(\delta^{87} \mathrm{Sr} \approx-1.0\right)$ showed an influence from biotite weathering, whereas older soils showed the progressive influence of plagioclase (lowering $\delta^{87} \mathrm{Sr}$ values; cf. Figure 1 ). The oldest soils showed a slight increase in $\delta^{87} \mathrm{Sr}$ relative to the plagioclasedominated soils, which was attributed to residual alkali feldspar weathering. Soil mineralogy in the White et al. (1992) study was documented by X-ray diffraction analysis.

Similar results have been reported by Blum et al. (1994). Stream water from a recently $(\sim 10 \mathrm{Ka})$ glaciated portion of a granitic batholith showed consistently higher $\delta^{87} \mathrm{Sr}$ values than stream water from a portion that had been glaciated less recently $(\sim 100 \mathrm{Ka})$. They attributed this to weathering of biotite from the fresher surfaces that were scoured more recently by the younger glaciation. The older surfaces showed less influence from biotite and greater influence from plagioclase. Blum et al. pointed out that an interesting implication of this is that glaciation of a 
granitic terrane may lead to a short-term increase in $\delta^{87} \mathrm{Sr}$ values in streams draining the region. This could be the cause of correlations that have been noted in seawater $\delta^{87} \mathrm{Sr}$ values and global climate cycles (Clemens et al., 1993).

Although most isotopic weathering studies have employed $\mathrm{Sr}$, Figure 2 indicates that in some instances, particularly for older rocks, $\mathrm{Pb}$ isotopes may be useful in tracking the weathering sequence. There would be very significant differences expected in $206 \mathrm{~Pb} / 204 \mathrm{~Pb}$ ratios within the minerals of granites older than about $100 \mathrm{Ma}$. While the weathering of amphibole cannot be readily distinguished from that of plagioclase using $\mathrm{Sr}$ isotopes, amphibole and plagioclase will likely have very distinctive $\mathrm{Pb}$ isotopic compositions. As was the case with $\mathrm{Sr}$, plagioclase and biotite will also have very distinctive $\mathrm{Pb}$ isotopic compositions (Figure 2). However, while biotite will have a higher ${ }^{87} \mathrm{Sr}$ value than plagioclase, it will have lower $\mathrm{Pb}$ isotopic compositions. During weathering of biotite and plagioclase the $\mathrm{Pb}$ isotopic compositions should vary inversely with the Sr isotopic compositions.

Erel et al. (1991) used the $\mathrm{Pb}$ isotopic compositions of stream water, lake water (with an anthropogenic signal), and leachate $\mathrm{Pb}$ to examine the $\mathrm{Pb}$ systematics in a mountain stream. The isotopic compositions indicated that the stream water $\mathrm{Pb}$ concentrations were controlled largely by natural weathering processes in local granitic rocks rather than an anthropogenic source. There are some potential complications to the use of $\mathrm{Pb}$ isotopes to elucidate hydrologic processes, including the strong possibility of anthropogenic contamination, the relative lack of immobility for $\mathrm{Pb}$ in groundwater, and the possibility for highly radiogenic $\mathrm{Pb}$ to exist in accessory minerals (e.g., apatite). But, in turn, each of these can also be used to advantage: anthropogenic $\mathrm{Pb}$ is easily identifiable by its isotopic composition, the differential mobility of $\mathrm{Pb}$ and $\mathrm{Sr}$ will produce covariation in concentrations in microenvironments, and the presence of accessory-phase $\mathrm{Pb}$ may allow unusually distinctive fingerprinting of both groundwater and weathering processes.

Infiltration of water through the unsaturated zone is a concern in both weathering studies and hydrograph separation analyses, and is also important to both recharge and solute transport studies. Thermonuclear ${ }^{36} \mathrm{Cl}$ has been used to assess amounts and depths of infiltration. Purdy et al. (1987) tracked the concentrations of ${ }^{36} \mathrm{Cl}$ in well water along a shallow $(<200 \mathrm{~m}$ ) flowpath in Aquia aquifer of Maryland. The concentrations surprisingly increased steadily along the flowpath. After considering and rejecting the possibility that the increase could be 
due to in-situ production, they concluded that it was likely due to infiltration recharge leaking into the Aquia aquifer from above.

Infiltration in arid regions using thermonuclear ${ }^{36} \mathrm{Cl}$ has been examined by a number of groups. The peak in atmospheric input of ${ }^{36} \mathrm{Cl}$ from the atmospheric nuclear weapons testing should have produced a corresponding peak in the soil columr. The soil peak represents an infiltration front. Cecil et al. (1992) measured ${ }^{36} \mathrm{Cl}$ in soil cores from the semi-arid Snake River Plain and found a sharp and welldefined peak in the ${ }^{36} \mathrm{Cl} / \mathrm{Cl}$ ratio at one meter depth (total soil depth was six meters). The infiltration rate calculated from this was $0.71 \mathrm{~cm} /$ year. This is about twice the rate derived from Darcian flux calculations based on neutron log data collected from the site over a four year period. Given the magnitude and sharp definition of the ${ }^{36} \mathrm{Cl}$ peak, it is difficult to accept that lower calculated Darcian flux infiltration estimate. Similar infiltration studies have been conducted by Phillips et al. (1988) and Norris et al. (1987). Each study demonstrated that a ${ }^{36} \mathrm{Cl}$ peak could be identified in the upper few meters of the soil column. The Norris et al. (1987) study, however, showed the difficulties that soil carbonates or mineralogical inhomogeneities could cause in interpreting the infiltration data.

Evaporation/Transpiration. A use of ${ }^{36} \mathrm{Cl}$ that is related to the infiltration studies is its use in estimating evapotranspirative losses (Paul et al., 1986; Margaritz et al, 1990). Either thermonuclear or natural cosmogenic ${ }^{36} \mathrm{Cl}$ can be used, although they must be distinguiahable within the system. Margaritz et al. (1990) compared the chloride concentration and ${ }^{36} \mathrm{Cl} / \mathrm{Cl}$ ratio of groundwater to the values measured in rainwater to determine the amount of water lost to evapotranspiration before the water reached the water table. The method is based on the increasing solute concentrations in infiltrating water. This increase is due to both evapotranspiration and $\mathrm{Cl}$ gained through rock leaching. The ratio of ${ }^{36} \mathrm{Cl}$ to total chloride is used to differentiate between these two processes. There will be a significant difference between the ${ }^{36} \mathrm{Cl} / \mathrm{Cl}$ ratio in the rock and that of the incoming precipitation. Therefore, the situation is a two endmamber mxing problem and by deconvoluting the endmembers, the amount of $\mathrm{Cl}$ added by rock leaching can be determined. In the semi-arid region of the Margaritz et al. study (the Jordan River catchment basin of Israel), the amount of water lost was generally in the range of 40 to 90 percent of the incoming precipitation. 
The Deep System: Groundwater Flow. Two important issues of concern in catchment hydrology are the flow paths and flow rates of groundwater within confined or unconfined aquifers. Compared to surface water, groundwater is within the system for a long period of time, and significant chemical interactions with the rock or soil of the aquifer can occur. Physically separated groundwater masses can be differentiated by marked differences in chemical compositions. Reaction path modeling of observed changes in the groundwater chemistry can indicate flow paths. These compositional differences and modeled chemical reactions are usually accompanied by isotopic changes in the lithogenic elements within the water.

In the Aberg et al. (1989) study discussed above, the progressive changes in $\delta^{87} \mathrm{Sr}$ values of leached exchangable $\mathrm{Sr}$ and lysimeter water $(\sim+46$ to $\sim+39)$ parallel changes in $\delta^{87} \mathrm{Sr}$ within the soil itself $(\sim+126$ to $\sim+86)$. In the what was refered to as a "deep" water sample, the $\delta^{87} \mathrm{Sr}$ value was much higher $(+102.5)$, but still not in isotopic equilibrium with the rock ( $\delta^{87} \mathrm{Sr}=+296.81$ ). This is similar to observed $\mathrm{Sr}$ compositions in the Wawona catchment of Yosemite National Park (Figure 6). The $\delta^{87} \mathrm{Sr}$ values for the youngest, most shallow waters (-0.28) represent early interaction with biotite (Nimz et al., 1992). Older, deeper waters progressively

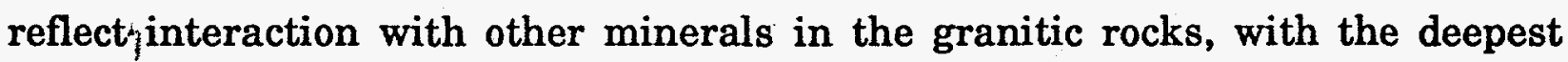
samples $\left(\delta^{87} \mathrm{Sr}=-2.75\right.$ ) being in isotopic equilibrium with the rock (rock $\delta^{87} \mathrm{Sr}=$ -3.10 to -2.40 ). Water with $\delta^{87} \mathrm{Sr}$ values most like the rock values has migrated along longer flow paths and had more time to interact with the rock.

There have been several studies that have deduced flow patterns on the basis of $U$ isotopic compositions in moderate sized drainage systems. Kronfeld et al. (1979) found $U$ isotopic variation to be quite systematic within the $\sim 1000 \mathrm{~km}^{2}$ Cenomanian carbonate aquifer system in the Beersheva region of Isreal. In general, $U$ activity values ranged from near secular equilibrium, 1.03, to values of nearly 2 . The systematic changes allowed Kronfeld et al. to propose flow paths that curved around the major axes of buried geologic structures in the study area. Andrews and Kay (1982) were able to discern regional flow paths along a zone approximately 150 $\mathrm{km}$ in length by the use of $234 \mathrm{U} / 238 \mathrm{U}$ activity ratio isopleths. Three distinct zones were identified where uranium laeching, uranium deposition, and interstitial fluid mixing occurred. Activity ratios in the system ranged from less than one to greater than three.

Variations in flow rates have also been observed using $U$ isotopic compositions. Kronfeld and Rosenthal (1981) collected water samples from Bet Shean and Harod 
valleys in Isreal, which comprise a single large drainage basin. The samples showed very small variations in $U$ concentrations $(\sim 1-4 \mu \mathrm{g} / \mathrm{L})$, but large variations in $234 \mathrm{U} / 238 \mathrm{U}$ activity ratios $(<1.5$ to $>3.0)$. Three distinct water masses were identified, two of which occurred in rocks with very similar lithologies (carbonates). Initial preferential leaching of ${ }^{234} \mathrm{U}$ created the highest activity ratios seen in the system; as the water further reacted with the rock, the activity ratios became lower as the result of $238 \mathrm{U}$ dissolution from areas previously laeched of ${ }^{234} \mathrm{U}$. For one of the carbonate units, the lowering of the activity ratio did not occur until the water was quite remote from the recharge area. In the other carbonate unit the lowering of the activity ratios occurred near the recharge areas. This difference was interpretted by Kronfeld and Rosenthal (1981) to be the result of lower permeability in the second carbonate unit. The relative flow rates between the units was very different, leading in one case to relatively old water near the recharge areas whereas in the other case water of the same age was able to flow much farther from the recharge area. The total distance along the flow path of this study was about 10 km. However, significant differences in activity ratios between the two water masses were detectable within about one kilometer of the recharge areas. These distançes are clearly sufficient for use on the catchment scale.

As discussed above, thermonuclear ${ }^{36} \mathrm{Cl}$ is very useful to discriminate recently recharged water from pre-bomb-pulse water. Cosmogenic ${ }^{36} \mathrm{Cl}$ may in certain instances be valuable on a catchmant scale, as is shown for the Wawona catchment in Figure 5. The water from the deepest Wawona well contains ${ }^{36} \mathrm{Cl} / \mathrm{Cl}$ ratios that are far below what would be expected for pre-bomb-pulse recharge input (Bentley et al., 1986a; see discussion above also). Determing the age of this water is complicated by in-situ ${ }^{36} \mathrm{Cl}$ production and other problems involving $\mathrm{Cl}$ migration (Nimz et al., 1993), but the ${ }^{36} \mathrm{Cl} / \mathrm{Cl}$ values clearly indicate that the chlorine in the water is quite old ( $>1 \mathrm{Ma}$ old, given modern input values and an assumption of nonmixing). Potentially, this information can be coupled with data concerning recharge location to derive a flow rate estimate for the water.

System (Basin) Closure: Mixing of Water Masses. The degree to which a catchment operates as a closed system is important when assessing hydrograph separation, water resource potential, and mass balance of both water and solutes. Solute concentrations are often used to assess the mixing of groundwater originating outside of a hydrologic system with water originating within the system 
(Christopherson and Hooper, 1992). Lithogenic and cosmgenic nuclides have also been used to assess mixing, but have received much less attention on the catchment scale than on the regional scale. Lithogenic and cosmogenic nuclides have the advantage that while elemental concentrations can vary due to mineral formation (precipitation) reactions, lithogenic and cosmogenic isotopic ratios will not. Crystallization reactions can obscure mixing relationships when only elelmental concentrations are considered without accompanying isotopic data.

Several references were given in the preceding section to groundwater mixing studies employing lithogenic nuclides. While each of these studies were regional in scope, the principles used are identical to those that would be used on the catchment scale. Smalley et al. (1988) were able to identify mixing between meteoric ("fresh") water and more evolved saline water on the basis of the $\mathrm{Sr}$ isotopic compositions of the endmembers. Lowry et al. (1988) were able to use $\mathbf{S r}$ isotopic compositions of groundwater samples to distinguish between three endmembers, one of which was meteoric. Having recognized the meteoric component as a "dilution" effect, they were able to model the mixing of the other two components by use of a ${ }^{87} \mathrm{Sr} / 86 \mathrm{Sr}$ - $\mathrm{Sr}$ concentration mixing curve. McNutt et al. (1984) were able to identify a lack of mixing in waters on the basis of $\mathrm{Sr}$ isotopes. This allowed them to realize the system consisted of what they termed "pockets" of water, each of which behaved as closed systems. Smalley et al. (1992) were able to determine a horizontal permeability barrier in oil reserviors through the use of $\mathrm{Sr}$ isotopic compositions in formation water and calcites from drill cores. Identification of mixing endmembers, identifying groundwater segregation, and locating permeability barriers are all relevant concerns in catchment hydrology.

The isotopic composition of uranium has been used to assess mixing in much the same way as that of Sr. Cuttell et al. (1988) were able on the basis of ${ }^{234} U / 238 \mathrm{U}$ ratios to distinguish three groundwater types in the Lower Mercy Basin of western England, as well as zones of mixing between them. Ivanovich and Alexander (1987) found systematic variations in $234 \mathrm{U} / 238 \mathrm{U}$ ratios between confined and unconfined groundwaters underlying Harwell, England. They were able to detect specific locations of leakage of the confined unit. Similar points of interconnection between groundwater masses were identified in central Isreal by Guttman and Kronfeld (1982). At these locations, $U$-enriched water was able to migrate downward into the underlying formation. These interconnections could be generally correlated with geologic structures in the region. It should be noted that each of these studies were 
conducted at a location that could be considered a large catchment; the studies are sampling relatively shallow water within areas that are less than a few hundred square kilometers in size.

The cosmogenic isotopes ${ }^{3} \mathrm{H}$ and ${ }^{14} \mathrm{C}$ have been widely used to assess groundwater mixing. The use of ${ }^{36} \mathrm{Cl}$ for this purpose is increasing. The order of magnitude or greater difference between atmospheric ${ }^{36} \mathrm{Cl} / \mathrm{Cl}$ ratios and rock equilibrium ratios can make mixing between recharge water and older water easy to identify. The very large difference between natural ${ }^{36} \mathrm{Cl}$ levels and thermonuclear ${ }^{36} \mathrm{Cl}$ levels lends itself easily to groundwater mixing studies. Dowgiallo et al. (1990) examined the ${ }^{36} \mathrm{Cl} / \mathrm{Cl}$ ratios in water of the Mazowsze artesian basin of central Poland. Here, mixing of water containing atmospheric ${ }^{36} \mathrm{Cl}$ with older water containing low ${ }^{36} \mathrm{Cl} / \mathrm{Cl}$ ratios was identified as the primary mechanism for decreases in ${ }^{36} \mathrm{Cl} / \mathrm{Cl}$ along the presumed flow path. However, certain samples in intermediate locations along the flow path had ${ }^{36} \mathrm{Cl} / \mathrm{Cl}$ ratios that were too high for the modeled dilution curves. The higher values could not be explained by in-situ production of ${ }^{36} \mathrm{Cl}$ because the aquifer rocks contained low $U$ and $T h$ concentrations. Since the basin is artesian, downward leakage (recharge) of water with an atmospheric or thermonuclear ${ }^{36} \mathrm{Cl}$ component was improbable. Consequently, Dowgiallo et al. (1990) interpreted the increases to points of upward leakage of water from an underlying the confined aquifer taht was known to contain high concentrations of $U$ and Th.

Bentley et al. (1986a) discuss a preliminary ${ }^{36} \mathrm{Cl}$ study that was conducted in a large enclosed basin in Brazil (the Drought Polygon) in which water quality was a problem due to high $\mathrm{Cl}$ contents. The high- $\mathrm{Cl}$ water was meteoric, as could be determined by its atmospheric ${ }^{36} \mathrm{Cl} / \mathrm{Cl}$ ratios. However, on the basis of a mixing array observed in the ${ }^{36} \mathrm{Cl} / \mathrm{Cl}$ values, a second water was infered to exist at depth in the basin. Component mixing diagrams indicated that the second water contained low concentrations of $\mathrm{Cl}$. Although the study was preliminary, it was suggested that a solution to the water quality problems in the basin might be to bypass the shallow high-Cl water and tap the deeper low-Cl water.

Carlson et al. (1990) were able to identify contributions to the chloride in three lakes in Antarctica on the basis of ${ }^{36} \mathrm{Cl} / \mathrm{Cl}$ ratios. Chloride from a river source (atmospheric ${ }^{36} \mathrm{Cl} / \mathrm{Cl}$ ) was distinguished from chloride from deep groundwater (low ${ }^{36} \mathrm{Cl} / \mathrm{Cl}$ ) on the basis of mixing curves for lake samples. A third component in one of the lakes could be identified as a seawater source, and the possibilty of a seawater 
incursion was suggested. Although we have not discussed the role of lithogenic or cosmogenic nuclides in catchment lakes, the Carlson et al. study clear indicates the potential for their use.

The possibility of groundwater mixing in the $1.7 \mathrm{~km}^{2}$ Wawona catchment of Yosemite National Park is suggested by Figure 6. Some of the wells at intermediate depths (50-100 meters) have ${ }^{36} \mathrm{Cl} / \mathrm{Cl}$ ratios that either represent pre-bomb-pulse atmospheric values $\left(200-400 \times 10^{-15}\right)$ or mixing between water containing bombpulse ${ }^{36} \mathrm{Cl}$ and deeper old water.

Streamflow: Mass Balance Within the Catchment. For a catchment that is a mostly closed system, mass balance within the system can be assessed through chemical analysis of precipitation and dry deposition (input), and stream water (output; Cleaves et al., 1970; Hooper et al., 1990; Mast et al., 1990; Stauffer and Wittchen, 1991; Wilson et al., 1991a; 1991b). Lithogenic and cosmogenic isotopic compositions can be useful in these studies not only by identifying the sources for the solutes (as much of this paper discusses), but also by being able to place constraints on the acceptable volumes of each solute from identified sources. For example, if it is thought that $20 \%$ of the $\mathrm{Sr}$ in a stream during stormflow comes from surface or near-surface (interflow) sources, then $20 \%$ of the isotopic composition of the $\mathrm{Sr}$ in the stream must reflect these sources. Further, the stream could be expected to have at least a $20 \%$ component of atmospheric ${ }^{36} \mathrm{Cl}$ (perhaps itself with some thermonuclear component), since the surface water would have atmospheric ${ }^{36} \mathrm{Cl}$ values (special circumstances, such as surface halite dissolution, excepted). The isotopic compositions of the solutes serve as a check on the solute mass balance assumptions. This approach has been used by several of the studies discussed in this section (Aberg et al., 1989; White et al., 1992; Blum et al., 1994).

\section{Lithogenic and Cosmogenic Nuclides: Summary}

The preceding sections have attempted to summarize the processes that affect lithogenic and cosmogenic nuclides in hydrologic systems, and to discuss how knowledge of these processes can be used to better understand catchment hydrology. The important consideration for both lithogenic and cosmogenic nuclides is the chemical behavior within the system of the solute under consideration. One must consider the various sources of the solute, where the sources are located 
within the system, and to what degree each source will likely contribute to the overall isotopic budget within catchment water. Unlike considerations based only on solute concentrations, isotopic considerations permit the source of the solute to be identified. It is this identification of sources that can be used to examine mass input into the system, hydrograph separation, weathering reactions, infiltration paths and rates, evapotranspiration losses, groundwater flow paths and flow rates, groundwater mixing within the system, and general mass balance of the system.

There are as yet very few published studies employing lithogenic or cosmogenic nuclides that focus specifically on catchment hydrology. Despite the fact that the lack of such studies thusfar makes the entire subject a "new direction" in catchment hydrology, there are areas that can be considered truly new directions because their applications in hydrology on any scale are today almost completely unexplored. The following concluding sections of this paper discuss potential applications.

\section{New Directions in Lithogenic and Cosmogenic Nuclides}

The Other Geologic Giant: Neodymium. Besides $\mathrm{Sr}$ and $\mathrm{Pb}$, the other lithogenic element having received widespread use in geology is $\mathrm{Nd}$ (Table 1). Important elemental fractionations occur in nature between ${ }^{143} \mathrm{Nd}$ and its parent ${ }^{147} \mathrm{Sm}$, creating varying $\mathrm{Nd}$ isotopic compositions $\left({ }^{143} \mathrm{Nd} / 144 \mathrm{Nd}\right)$ through radiodecay. This has made $\mathrm{Nd}$ useful for age dating as well as many other geologic applications (DePaolo, 1988). Because the natural abundance of $\mathrm{Nd}$ is very small, and $\mathrm{Nd}$ is a very non-hydrophilic element in low temperatures environments, the concentration of Nd in natural waters is extremely low (Table 2). Nonetheless, Nd isotopic composition can be measured in natural waters (Goldstein and Jacobsen, 1987; Bullen and Kharaka, 1992). The isotopic composition of $\mathrm{Nd}$ varies systematically, though inversely, with the isotopic composition of $\mathrm{Sr}$ in most geologic environments (DePaolo, 1988). Therefore, as a hydrologic tracer, $\mathrm{Sr}$ would be the analyte of preference due to its higher concentration in natural waters. This is provided, of course, that the $\mathrm{Sr}$ and $\mathrm{Nd}$ originated from the same geologic source (e.g., the same aquifer rock). However, $\mathrm{Sr}$ and $\mathrm{Nd}$ do not have the same chemical behavior in all environments and in some groundwater samples may not be derived from the same geologic source. For example, Piepgras and Wasserberg (1985) noted that in geothermal environments $\mathrm{Nd}$ has a high affinity for water. An isotopic composition of Nd developed in geothermal environments would be unlikely to change if the 
water migrated away from the thermal area. A "fossil" Nd isotopic signature would remain in the water. The $\mathrm{Sr}$ isotopic composition obtained in the thermal area would likely not be retained as $\mathrm{Sr}$ from the non-thermal zone would dissolve into the water, mixing or exchanging with the thermal $\mathrm{Sr}$. In this case, $\mathrm{Nd}$ could serve as a useful hydrologic tracer. As is always the case with lithogenic nuclides, one must consider the geochemical behavior of the element of interest.

Except in very specific environments, $\mathrm{Nd}$ will not be as useful as $\mathrm{Sr}$ to interpret the weathering process in rocks and minerals. Because of their similar geochemical behavior, $\mathrm{Sm}$ and $\mathrm{Nd}$ are not fractionated from one another as severely as $\mathrm{Rb}$ and Sr. This fact, combined with the very long half-life of ${ }^{147} \mathrm{Sm}\left(1.53 \times 10^{-11}\right.$ years $)$, make inter-mineralic variations in $\mathrm{Nd}$ isotopes fairly small unless the system is quite old. Figure 7 shows $\mathrm{Nd}$ isotopic variations with time in a hypothetical garnet gneiss with similar mineralogy to the granite used in the $\mathrm{Sr}$ and $\mathrm{Pb}$ examples (Figures 1 and 2). Garnet is one of the few common, non-accessory, minerals to significantly fractionate $\mathrm{Sm}$ from $\mathrm{Nd}$ during its formation. In the example, $\mathrm{Nd}$ derived through weathering of garnet would be analytically resolvable from $\mathrm{Nd}$ derived from the rest of the rock, even at a fairly young rock age. Analytical precisign is generally about ${ }^{1}$ unit on the epsilon scale. The Nd from the other mineral would therefore be difficult to distinguish until the age of the rock reach several hundred million years. In some cases then, $\mathrm{Nd}$ isotopic compositions might be useful to track weathering reactions, although in most of these cases, $\mathrm{Sr}$ would probably be more useful.

Lithogenic Elements With Fractionating Isotopes. Several elements derived through water-rock interactions have stable isotopes that are fractionated from one another by common natural processes. Three will be discussed briefly here: $\mathrm{Li}, \mathrm{B}$, and $\mathrm{Cl}$. The two naturally-occurring isotopes of $\mathrm{Li},{ }^{6} \mathrm{Li}$ and ${ }^{7} \mathrm{Li}$, fractionate substantially during a wide variety of naturally processes, including mineral formation (chemical precipitation), metabolism, ion exchange, and rock alteration (Morozova and Alferovskiy, 1974; Chan and Edmond, 1988). Unfortunately, the ease with which Li fractionates has made laboratory isotopic analysis very difficult in the past. The $\mathrm{Li}$ isotopic fractionation during mass spectrometric analysis could not be controlled or sufficiently characterized. Recently, however, techniques have been developed that appear very promising (Chan, 1987; Xiao and Beary, 1989). Lithium is sufficiently abundant in the earth's crust and in natural waters (Table 2) that $\mathrm{Li}$ will 
undoubtedly be useful in hydrologic assessments. Bullen and Kharaka (1992) examined the $\mathrm{Li}$ isotopic compositions from thermal waters of Yellowstone National Park. Because the isotopes will fractionate during hydrothermal processes, it is not surprising that significant variations in the ${ }^{7} \mathrm{Li} / 6 \mathrm{Li}$ ratios were observed at Yellowstone. The variations permitted Bullen and Kharaka to discriminate water derived from marine sedimentary rocks from water associated with hydrothermally altered igneous rocks, thereby aiding in the interpretation of regional groundwater flow paths.

Like lithium, boron shows a high degree of mobility in nature, and has two stable isotopes that are easily fractionated by a variety of natural processes ( ${ }^{1} 0 \mathrm{~B}$ and $\left.{ }^{11} \mathrm{~B}\right)$. The $\mathrm{B}$ isotopes are fractionated during $\mathrm{H}_{2} \mathrm{O}$ phase changes in hydrothermal systems (Spivack et al, 1990; Leeman et al, 1992), during hydrothermal alteration of rock (Spivack, 1985), during mineral crystallization (Oi et al., 1989), and during the adsorption of dissolved B onto clay minerals (Schwarcz et al., 1969). The latter effect may be responsible for the large ${ }^{11} \mathrm{~B}$ enrichment in seawater relative to both oceanic crust (Spivack and Edmond, 1987) and continental crust (Spivack et al., 1987). All of these effects combine to produce B isotopic variations in hydrologic systems that can be very useful. They have been used to trace the origin of water masses (Palmer and Sturchio, 1990; Xiao et al., 1992), to track the evolution of brines (Vengosh et al., 1991a; 1991b; Moldovanyi et al., 1993), to determine the origin of evaporites (Swihart et al., 1986; Vengosh et al., 1992), and to examine hydrothermal flow systems (Leeman et al., 1992). There are many aspects of B isotopic systematics that remain poorly understood (see discussions in Vengosh et al., 1992; and Bassett, 1990). Under the appropriate circumstances, and depending on which questions were being asked, boron could have applications in catchment hydrology. It is apparent from the published literature, however, that more work is needed to understand the behavior of boron isotopes before its use in catchments would be routine.

Like $\mathrm{Li}$ and $\mathrm{B}, \mathrm{Cl}$ has two stable isotopes $\left({ }^{35} \mathrm{Cl}\right.$ and $\left.{ }^{37} \mathrm{Cl}\right)$ and is highly mobile in the hydrosphere. Unlike the isotopes of those two elements, however, $\mathrm{Cl}$ isotopes are not widely fractionated in nature. Small variations in $\mathrm{d}^{37} \mathrm{Cl}$ values $(<2.1 \%$ ) were reported by Kaufman et al. (1984) in a number of different water types. Variations in $\mathrm{d}^{37} \mathrm{Cl}$ values ranged from -1.29 to +0.53 in deep groundwaters from Texas. Smaller, though still significant differences were reported for formation waters from the Michigan Basin (Kaufman et al., 1993). Desaulniers et al. (1986) 
reported evidence suggesting $\mathrm{Cl}$ isotope fractionation during diffusion-controlled processes in groundwater from Quaternary glacial deposits. Fractionation also can occur during high-temperature water-rock interactions (Eastoe et al., 1989). The ratio may also be affected by temperature variation in the ocean reservoir through time (Kaufman et al., 1993). Therefore, although there are no low-temperature fastkinetic fractionation mechanisms for $\mathrm{Cl}$ isotopes, there are sufficient isotopic variations in nature to make $\mathrm{d}^{37} \mathrm{Cl}$ useful as a hydrologic tracer. Depending on catchment lithology, the $\mathrm{Cl}$ isotopes might be useful for hydrograph separation analysis and determination of region-groundwater/catchment-groundwater mixing.

New Directions in Catchment Hydrology for Cosmogenic Nuclides. In catchment hydrologic applications, all cosmogenic nuclides except ${ }^{3} \mathrm{H}$ and ${ }^{14} \mathrm{C}$ can be considered "new directions". The uses of ${ }^{36} \mathrm{Cl}$ and ${ }^{129} \mathrm{I}$ discussed above are all today less than 10 years old, and many of the potential applications have not yet been attempted. Two cosmogenic nuclides that have had little or no attention in hydrology, but may have significant potential are ${ }^{10} \mathrm{Be}$ and ${ }^{41} \mathrm{Ca}$ (Table 1 ). Cosmogenically produced (in-situ) ${ }^{10} \mathrm{Be}$ has been used to examine soil erosion (Pavich et al., 1985), regolith soil formation (Barg et al., 1992), and development of lateritic soils (Bernat et al., 1990). The use of ${ }^{10} \mathrm{Be}$ present in authigenic material in weathering soils appears to be a valuable tool for dating the soil minerals and thereby determing soil formation rates (Barg et al., 1992). The ${ }^{10} \mathrm{Be} /{ }^{9} \mathrm{Be}$ ratio has been measured in river waters and associated sediments (Brown et al., 1992), and in atmospheric deposition (Brown et al., 1989). The cosmogenic nuclide ${ }^{7} \mathrm{Be}$ has been used in at least one catchment study to estimate top-soil particle movement (Dominik et al., 1987). However, ${ }^{7} \mathrm{Be}$ has a half-life of only about 53 days and its use in catchment hydrologic studies will therefore be limited. The utility of the isotopes of $\mathrm{Be}$ may lie in their lithophile character; $\mathrm{Be}$ is not extremely mobile in the hydrosphere, tending to strongly sorb onto mineral surfaces.

Calcium is one of the most useful elements to hydrologic studies, participating in a wide variety of hydrochemical processes. For this reason, ${ }^{41} \mathrm{Ca}$ may have-utility in hydrologic studies. Calcium- 41 is produced by a neutron reaction with ${ }^{40} \mathrm{Ca}$, and most of its production will therefore be in the upper meter or so of the soil column where $\mathrm{Ca}$ is abundant. Because the half-life of ${ }^{41} \mathrm{Ca}$ is about 100,000 , the hydrochemical cycling of ${ }^{41} \mathrm{Ca}$ atoms could be substantial. The geochemical behaviors of $\mathrm{Ca}$ and $\mathrm{C}$ are, of course, closely related through calcite formation and 
dissolution. This would suggest that ${ }^{41} \mathrm{Ca}$ may be useful in studies that are focused on the carbon cycle. Natural levels of ${ }^{41} \mathrm{Ca} / \mathrm{Ca}$ are on the order of $10^{-16}$ to $10^{-13}$, within the analytical abilities of modern accelerator mass spectrometry (Kutschera, 1990). No published studies have as yet applied ${ }^{41} \mathrm{Ca}$ to hydrology. 


\section{REFERENCES}

Aberg, G., G. Jacks, and P.J. Hamilton (1989) Weathering rates and ${ }^{87} \mathrm{Sr} /{ }^{86} \mathrm{Sr}$ ratios: An isotopic approach. J. Hydrol. 109, 65.

Andrews, J.N. and J-C. Fontes (1993) Comment on "Chlorine 36 dating of very old groundwater 3. Further studies in the Great Artesian Basin, Australia" by T. Torgersen et al.. Water Resour. Res. 29, 1871.

Andrews, J.N. and R.L.F. Kay (1978) The evolution of enhanced ${ }^{234} \mathrm{U} / 238 \mathrm{U}$ activity ratios for dissolved uranium and ground-water dating. In: Short Paper of the Fourth International Conference, Geochronology, Cosmochronology, Isotope Geology: U.S. Geological Survey Open-file Report 78-701.

Andrews, J.N. and R.L.F. Kay (1982) ${ }^{234} \mathrm{U} / 238 \mathrm{U}$ activity ratios of dissolved uranium in groundwaters from a Jurassic Limestone aquifer in England. Earth Planet. Sci. Lett. 57, 139.

Andrews, J.N. and R.L.F. Kay (1983) The $U$ contents and ${ }^{234} \mathrm{U} / 238 \mathrm{U}$ activity ratios of dissolved uranium in groundwaters from some Triassic sandstones in England. Chem. Geol. Isot. Geosci. 1, 101.

Andrews, J.N., I.S. Giles, R.L.F. Kay, D.J. Lee, J.K. Osmond, J.B. Cowart, P. Fritz, J.F. Barker, and J. Gale (1982) Radioelements, radiogenic helium and age relationships for groundwaters from the granites at Stripa, Sweden. Geochim. Cosmochim. Acta 46, 1533.

Andrews, J.N., J-Ch. Fontes, J-L. Michelot, and D. Elmore (1986) In-situ neutron flux, ${ }^{36} \mathrm{Cl}$ production and groundwater evolution in crystalline rocks at Stripa, Sweden. Earth Planet. Sci. Lett. 77, 49.

Banner, J.L. and G.N. Hanson (1990) Calculation of simultaneous isotopic and trace element variations during water-rock interaction with applications to carbonate diagenesis. Geochim. Cosmochim. Acta 54, 3123.

Banner, J.L., G.J. Wasserberg, J.H. Chan, and C.H. Moore (1990) 234 U-238U-230Th${ }^{232} \mathrm{Th}$ systematics in saline groundwaters from central Missouri. Earth Planet. Sci. Lett. 101, 296.

Barg, E., D. Lal, A.J.T. Jull, J. Southon, M.W. Caffee, R.C. Finkel, M. Pavich (1992) Applications of cosmogenic nuclear methods for studying soil erosion and formation rates. In: Kharaka, Y.K. and A.S. Maest (1992) Water-Rock Interaction, Proceedings of the 7th International Symposium on Water-Rock Interaction, Balkema Publishers, Rotterdam, p. 541. 
Bassett, R.L. (1990) A critical evaluation of the available measurements for the stable isotopes of boron. Appl. Geochem. 5, 541.

Beasley, T.M., L.D. Cecil, P. Sharma, P.W. Kubik, U. Fehn, L.J. Mann, and H.E. Gove (1993) Chlorine-36 in the Snake River Plain aquifer at the Idaho National Engineering Laboratory: Origin and implications. Groundwater 31, 302.

Bentley, H.W., F.M. Phillips, and S.N. Davis (1986a) Chlorine-36 in the terrestrial environment. In: Handbook of Environmental Geochemistry (P. Fritz and J.-Ch. Fontes, eds.). Elsevier, Amsterdam. p. 427.

Bentley, H.W., F.M. Phillips, S.N. Davis, S. Gifford, D. Elmore, L.E. Tubbs, and H.E. Gove (1982) Thermonuclear ${ }^{36} \mathrm{Cl}$ pulse in natural waters. Nature 300, 737.

Bentley, H.W., F.M., Phillips, S.N. Davis, M.A. Hebrmehl, P.L. Airey, G.E. Calf, D. Elmore, H.E. Gove, and T. Torgersen (1986b) Chlorine-36 dating of very old groundwater 1. Thre Great Artesian Basin, Australia. Water Resour. Res. 22, 1991.

Bernat, M., J.E. Bokilo, F. Yiou, G.M. Raisbeck, and J-P. Muller (1990) ${ }^{10}$ Be and natural isotopes of $U$ and $T h$ in a laterite cover from Camaroon. Chem. Geol. $84,347$.

Blum, J.D., Y. Erel, and K. Brown (1994) ${ }^{87} \mathrm{Sr} / 86 \mathrm{Sr}$ ratios of Sierra Nevada stream waters: Implications for relative mineral weathering rates. Geochim. Cosmochim. Acta 58, 5019.

Bowen, N.L. (1928) The Evolution of the Igneous Rocks. Princeton University Press, Prineton, New Jersey.

Brown, E.T., J.M. Edmond, G.M. Raisbeck, D.L. Bourles, F. Yiou, and C.I. Measures (1992) Beryllium isotope geochemistry in tropical river basins. Geochim. Cosmochim. Acta 56, 1607.

Brown, L., G.J. Stensland, J. Klein, and R. Middleton (1989) Atmospheric deposition of ${ }^{7} \mathrm{Be}$ and ${ }^{10} \mathrm{Be}$. Geochim. Cosmochim. Acta 53, 135.

Bullen, T.D. and Y.K. Kharaka (1992) Isotopic composition of $\mathrm{Sr}, \mathrm{Nd}$, and $\mathrm{Li}$ in thermal waters from the Norris-Mammoth corridor, Yellowstone National Park and surrounding region. Water-Rock Interaction, Proceedings of the 7th International Symposium on Water-Rock Interaction, Balkema Publishers, Rotterdam, p. 897. 
Caffee, M.W., R.C. Finkel, G.J. Nimz, J. Borchers (1992) Isotopic composition of chlorine in groundwater from the Wawona basin, Yosemite National Park. Eos, Transaction, American Geophysical Union 73, 173.

Capo, R.C. and O.A. Chadwick (1993) Application of strontium isotopes to the mass balance of calcium in desert soils: Eolian input vs. in-situ weathering. Geol. Soc. Am. Abstr.Progr. 25, A-394.

Carlson, C.A., F.M. Phillips, D. Elmore, and H.W. Bentley (1990) Chlorine-36 tracing of salinity sources in the Dry Valleys of Victoria Land, Antarctica. Geochim. Cosmochim. Acta 54, 311.

Cecil, L.D., J.R. Pitman, T.M. Beaseley, R.L. Michel, P.W. Kubik, P. Sharma, U. Fehn, and H.E. Gove (1992) Water infiltration rates in the unsatuaretd zone at the Idaho National Engineering Laboratory estimated from chlorine-36 and tritium profiles, and neutron logging. In: Kharaka, Y.K. and A.S. Maest (1992) Water-Rock Interaction, Proceedings of the 7th International Symposium on Water-Rock Interaction, Balkema Publishers, Rotterdam, p. 709.

Chan, L-H. (1987) Lithium isotope analysis by thermal ionization mass spectrometry of lithium tetraborate. Anal. Chem. 59, 2662.

Chan, L-H. and J.M. Edmond (1988) Variations in lithium isotope composition in the marine envirnment: A prelimiary report. Geochim. Cosmochim. Acta 52, 1711.

Cherdyntsev, V.V., P.I. Chalov, and G.Z. Khaidarov (1955) Transactions of the Third Session of the Committee for Determination of Absolute Ages of Geologic Foramtions: Izv. Nauk. SSR. p. 175.

Christopherson, N. and R.P. Hooper (1992) Multivariate analysis of stream water chemical data: The use of principal components analysis for the end-member mixing problem. Water Resour. Res. 28, 99.

Cleaves, E.T., A.E. Godfrey, O.P. Bricker (1970) Geochemical balance of a small watershed and its geomorphic implications. Bull. Geol. Soc. Am. 81, 3015.

Clemens, S.C., J.W. Farrell, and L.P. Gromet (1993) Synchronous changes in seawater strontium isotope composition and global climate. Nature 363, 607.

Collerson, K.D., W.J. Ullman, and T. Torgerson (1988) Ground waters with unradiogenic ${ }^{87} \mathrm{Sr} /{ }^{86} \mathrm{Sr}$ ratios in the Great Artesian Basin, Australia. Geology 16,59 . 
Connolly, C.A., L.M. Walter, H. Baadsgaard, and F.J. Longstaffe (1990) Origin and evolution of formation waters, Alberta Basin, western Canada sedimentary basin. II. Isotope systematics and water mixing. Appl. Geochem. 5, 397.

Curtis, C.D. (1976) Stability of minerals in surface weathering reactions: A general thermochemical approach. Earth Surf. Processes 1, 63.

Cuttell, J.C., J.W. Lloyd, and M. Ivanovich (1986) A study of uranium and thorium series isotopes in Chalk groundwaters of Lincolnshire, U.K.. J. Hydrol. 86, 343. Cuttell, J.C., M. Ivanovich, J.H. Tellam, and J.W. Lloyd (1988) Uranium-series isotopes in the groundwater of the Permo-Triassic sandstone aquifer, LowerMercey Basin, U.K. Appl. Geochem. 3, 255.

Davisson, M.L. and R.E. Criss (1993) Stable isotope imaging of a dynamic groundwater system in the southwestern Sacramento Valley, California, USA. J. Hydrol. 144, 213.

DePaolo, D.J. (1988) Neodymium Isotope Geochemistry, An Introduction. SpringerVerlag, Berlin.

Desaulniers, D.E., R.S. Kaufman, J.A. Cherry, and H.W. Bentley (1986) ${ }^{37} \mathrm{Cl}-{ }^{35} \mathrm{Cl}$ variations in a diffusion-controlled groundwater system. Geochim. Cosmochim. Acta 50, 1757.

DeWalle, D.R., B.R. Swistock, and W.E. Sharpe (1988) Three-component tracer model for stormflow on a small Appalchian forested catchment. J. Hydrol. 104, 301.

Dowgiallo, J., Z. Nowicki, J. Beer, G. Bonani, M. Suter, H.A. Synal, and W. Wolfli (1990) ${ }^{36} \mathrm{Cl}$ in ground water of the Mazowsze basin (Poland). J. Hydrol. 118, 373.

Drever, J.I. (1988) The Geochemistry of Natural Waters. Second Edition. PrenticeHall, Englewood Cliffs, New Jersey.

Drever, J.I. and D.R. Hurcomb (1986) Neutralization of atmospheric acidity by chemical weathering in an alpine drainage basin in the North Cascade Mountains. Geology 14, 221.

Eastoe, C.J., J.M. Guilbert, and R.S. Kaufman (1989) Preliminary evidence for fractionation of stable chlorine isotopes in ore-forming systems. Geology 17, 285.

Erel, Y. J.J. Morgan, C.C. Patterson (1991) Natural levels of lead and cadmium in a remote mountain stream. Geochim. Cosmochim. Acta 55, 707. 
Fabryka-Martin, J. S.N. Davis, D. Elmore, and P.W. Kubik (1989) In-situ production and migration of 1291 in the Stripa granite, Sweden. Geochim. Cosmochim. Acta 53, 1817.

Fabryka-Martin, J., D.O. Whittemore, S.N. Davis, P.W. Kubik, and P. Sharma (1991) Geochemistry of halogens in the Milk River aquifer, Alberta, Canada. Appl. Geochem. 6, 447.

Fabryka-Martin, J., H. Bentley, D. Elmore, and P.L.Airey (1985) Natural iodine-129 as an environmental tracer. Geochim. Cosmochim. Acta 49, 337.

Fabryka-Martin, J., S.N. Davis, D. Roman, P.L. Airey, D. Elmore, and P.W. Kubik (1988) Iodine-129 and chlorine-36 in uranium ores 2. Discussion of AMS measurements. Chem. Geol. Isot. Geosci. 72, 7.

Fehn, U. S. Tullai, R.T.D. Yeng, D. Elmore, and P.W. Kubik (1987) Determination of ${ }^{129}$ I in heavy residues of two crude oils. Nucl. Instr. Meth. Phys. Res. B29, 380.

Fehn, U., E.K. Peters, S. Tullai-Fitzpatrick, P.W. Kubik, P. Sharma, R.T.D. Teng, H.E. Gove, and D. Elmore (1992) ${ }^{129} \mathrm{I}$ and ${ }^{36} \mathrm{Cl}$ concentrations in waters of the eastern Clear Lake area, California: Residence times and source ages of hydrothermal fluids. Geochim. Cosmochim. Acta 56, 2069.

Fleischer, R.L. (1982) Alpha-recoil damage and solution effects in minerals: Uranium isotopic disequilibrium and radon release. Geochim. Cosmochim. Acta 46, 2191.

Fleischer, R.L. (1983) Theory of alpha recoil effects on radon release and isotopic disequilibrium. Geochim. Cosmochim. Acta 47, 779.

Fleischer, R.L. (1988) Alpha-recoil damage: Relation to isotopic disequilibrium and leaching of radionuclides. Geochim. Cosmochim. Acta 52, 1459.

Frohlich, K. and R. Gellerman (1987) On the potential use of uranium isotopes for groundwater dating. Chem. Geol. Isot. Geosci. 65, 67.

Garrels, R.M. and F.T. MacKenzie (1967) Origin of the chemical compositions of some springs and Lakes. In: Equilibrium Concepts in Natural Water Systems, (R.F. Gould ed.; W. Stumm, Symposium Chair) Advances in Chemistry Series 67, American Chemical Society, Washington, D.C., p. 222.

Garrels, R.M. and F.T. MacKenzie (1971) Evolution of Sedimentary Rocks. W.W. Norton and Co., New York.

Goldich, S.S. (1938) A study of rock weathering. J. Geol. 46, 17. 
Goldstein, S.J. and S.B. Jacobsen (1987) The Nd and Sr isotopic systematics of river-water dissolved material: Implications for the sources of $\mathrm{Nd}$ and $\mathrm{Sr}$ in seawater. Chem. Geol. Isot. Geosci. 66, 245.

Graustein, W.C. and R.L. Armstrong (1980) The use of strontium-87/strontium-86 ratios to measure atmospheric transport into forested watersheds. Science $\mathbf{2 1 9}$, 289.

Guthrie, V. (1991) Determination of recent ${ }^{238} \mathrm{U},{ }^{234} \mathrm{U}$, and ${ }^{230} \mathrm{Th}$ mobility in granitic rocks: Application of a natural analogue to the high-level waste repository environment. Appl. Geochem. 6, 63.

Guttman, J. and J. Kronfeld (1982) Tracing interaquifer connections in the Kefar Uriyya-Agur region (Isreal), using natural uranium isotopes. J. Hydrol. 55, 145.

Haberstock, G., J. Heinzl, G. Korschinek, H. Morinaga, E. Nolte, U. Ratzinger, K. Kato, and M. Wolf (1986) Accelerator mass spectrometry with heavy ions. Nucl. Instr. Meth. Phys. Res. B17, 385.

Helgeson, H.C., R.M. Garrels, and F.T. MacKenzie (1969) Evaluation of irreversible reactions in geochemical processes involving minerals and aqueous solutions: II. Applications. Geochim. Cosmochim. Acta 33, 455.

Hem, J.D. (1989) Study and Interpretation of the Chemical Characteristics of Natural Water. U.S. Geological Survey Water-Supply Paper 2254.

Hooper, R.P., N. Christopherson, and N.E. Peters (1990) Modelling streamwater chemistry as a mixture of soilwater endmembers - An application to the Panola Mountain catchment, Georgia, USA. J. Hydrol. 116, 321.

Huang, H.W., M. Maurette, and R.M. Walker (1967) Observation of fossil $\alpha$-particle recoil tracks and their implications for dating measurements. In: Radioactive dating and Methods of Low Level Counting, International Atomic Energy Agency, Vienna,. p. 415.

Hudson, G.B., M.L. Davisson, G.J. Nimz, J.K. Bohlke, and J.W. Borchers (1993) Isotopic segregation of ground water in the fractures granitic rocks at Wawona, Yosemite National Park, California. Eos, Transaction, American Geophysical Union 74, 582.

Ivanovich, M. and J. Alexander (1987) Application of uranium-series disequilibrium to studies of groundwater mixing in the Harwell region, U.K.. Chem. Geol. Isot. Geosci. 66, 279. 
Ivanovich, M., K. Frohlich, and M.J. Hendry (1991) Uranium-series radionuclides in fluids and solids, Milk River aquifer, Alberta, Canada. Appl. Geochem. 6, 405. Jannik, N.O., F.M. Phillips, G.I. Smith, and D. Elmore (1991) A ${ }^{36} \mathrm{Cl}$ chronology of lacustrian sedimentation in the Pleistocene Owens River system. Bull. Geol. Soc. Am. 103, 1146.

Junge, C.E. and R.T. Werby (1958) The concentration of chloride, sodium, potassium, calcium, and sulfate in rain water over the United States. J. Meterol. 15, 417.

Kaufman, R., A. Long, H. Bentley, S. Davis (1984) Natural chlorine isotope variation. Nature $309,338$.

Kaufman, R., S.K. Frape, R. McNutt, and C. Eastoe (1993) Chlorine stable isotope distribution of Michigan Basin formation waters. Appl. Geochem. 8, 403.

Kigoshi, K. (1971) Alpha-recoil ${ }^{234} \mathrm{Th}$ : Dissolution into water and the ${ }^{234} \mathrm{U} / 238 \mathrm{U}$ disequilibrium in nature. Science $173,47$.

Kraemer, T.F. and Y.K. Kharaka (1986) Uranium geochemistry in geopressuresgeothermal aquifers of the U.S. Gulf Coast. Geochim. Cosmochim. Acta 50, 1233.

Krishnaswami, S., W.C. Graustein, K.K. Turekian, and J.F. Dowd (1982) Radium, thorium and radioactive lead isotopes in groundwaters: Application to the insitu determination of adsorption-desorption rate constants and retardation factors. Water Resour. Res. 18, 1663.

Kronfeld, J. and E. Rosenthal (1981) Uranium isotopes as a natural tracer in the waters of the Bet-Shean-Harod Valleys, Israel. J. Hydrol. 50, 179.

Kronfeld, J., E. Gradsztajn, and A. Yaniv (1979) A flow pattern deduced from uranium disequilibrium studies for the Cenomanian carbonate aquifer of the Beersheva region, Israel. J. Hydrol. 44, 305.

Langmuir,D. (1978) Uranium solution-mineral equilibria at low temperatures with applications to sedimentary ore deposits. Geochim. Cosmochim. Acta 42, 547.

Latham, A.G. and H.P. Schwarcz (1989) Review of the modelling of radionuclide transport from $U$-series disequilibria and of its use in assessing the safe disposal of nuclear waste in crystalline rock. Appl. Geochem. 4, 527.

Leeman, W.P., R.D. Vocke, and M.A. McKibben (1992) Boron isotopic fractionation between coexisting vapor and liquid in natural geothermal systems. In: Kharaka, Y.K. and A.S. Maest (1992) Water-Rock Interaction, Proceedings of 
the 7th International Symposium on Water-Rock Interaction, Balkema Publishers, Rotterdam, p. 1007.

Lehmann, B.E. and H.H. Loosli (1991) Isotopes formed by underground production.

In: Applied Isotope Hydrogeology, A Case Study in Northern Switzerland (F.J.Pearson et al., eds). Studies in Environmental Science 43. Elsevier, Amsterdam.

Lowry, R.M., G. Faure, D.I. Mullet, and L.M. Jones (1988) Interpretation of chemical and isotopic compositions of brines based on mixing and dilution, "Clinton" sandstones, eastern Ohio, USA. Appl. Geochem. 3, 177.

Margaritz, M., A. Kaufman, M. Paul, E. Boaretto, and G. Holos (1990) A new method to determine regional evapotranspiration. Water Resour. Res. 26, 1759.

Margaritz, M., A. Kaufman, Y. Levy, D. Fink, O. Meirav, and M. Paul (1986) ${ }^{36} \mathrm{Cl}$ in a halite layer from the bottom of the Dead Sea. Nature 320, 256.

Mast, M.A., J.I. Drever, and J. Baron (1990) Chemical weathering in the Loch Vale Watershed, Rocky Mountain National Park, Colorado. Water Resour. Res. 26, 2971.

McNutt, R.H. (1987) ${ }^{87} \mathrm{Sr} /{ }^{86} \mathrm{Sr}$ ratios as indicators of Water/rock interactions: Application to brines found in Precambrian age rocks from Canada. In: Saline Water and Gases in Crystalline Rocks, (P. Fritz and S.K. Frape, eds.). Geol. Assoc. Canada Special Paper 33, p. 81.

McNutt, R.H., S.K. Frape, and P. Fritz (1984) Strontium isotopic composition of some brines from the Precambrian shield of Canada. Chem. Geol. Isot. Geosci. $2,205$.

Miller, W.R. and J.I. Drever (1977a) Chemical weathering and related controls on surface water chemistry in the Absaroka Mountains, Wyoming. Geochim. Cosmochim. Acta 41, 1693.

Miller, W.R. and J.I. Drever (1977b) Water chemistry of a stream following a storm, Absaroka Mountains, Wyoming. Bull. Geol. Soc. Am. 88, 286.

Moldovanyi, E.P., L.M. Walter, and L.S. Land (1993) Strontium, boron, oxygen, and hydrogen isotope geochemistry of brines from basal strata of the Gulf-Coast sedimentary basin, USA. Geochim. Cosmochim. Acta 57, 2083.

Moran, J.E., U. Fehn, and J.S. Hanor (1993) Iodine-129 as a tracer for brine migration in the Louisiana Gulf Coast. Geol. Soc. Am. Abstr. Progr. 25, A-90.

Morozova, I.M. and A.A. Alferovskiy (1974) Fractionation of lithium and potassium isotopes in geological processes. Geochem. Int. 11, 17. 
Musgrove, M. and J.L. Banner (1993) Ragional ground-water mixing and the origin of saline fluids: Midcontinent, United States. Science 259, 1877.

Nabelek, P.I. (1987) General equations for modeling fluid-rock interaction using trace elements and isotopes. Geochim. Cosmochim. Acta 51, 1765.

Nakano, T., Y. Kajiwara, C.W. Farrell (1989) Strontium isotope constraint on the genesis of crude oils, oil-field brines, and Kuroko ore deposits from the Green Tuff region of northeastern Japan. Geochim. Cosmochim. Acta 53, 2683.

Nimz, G.J., D.K. Smith, M.W. Caffee, R.C. Finkel, G.B. Hudson, J.W. Borchers, and K.P. Nimz (1992) Isotopic characterization of hydrologic structure and chemical interaction between groundwater and granitic rock in the Wawona basin, Yosemite National Park. Eos, Transaction, American Geophysical Union 73, 170.

Nimz, G.J., M.W. Caffee, and J.W. Borchers (1993) Extremely low ${ }^{36} \mathrm{Cl} / \mathrm{Cl}$ values in deep ground water at Wawona, Yosemite National Park, California: Evidence for rapid upwelling of deep crustal waters? Eos, Transaction, American Geophysical Union 74, 582.

Norris, A.E., K. Wolfsberg, S.K. Gifford, H.W. Bentley, and D. Elmore (1987) Infiltration at Yucca Mountain, Nevada, traced by ${ }^{36} \mathrm{Cl}$. Nucl. Instr. Meth. Phys. Res. B29, 376.

Oi, T., M. Nomura, M. Musashi, T. Ossaka, M. Okamoto, and H. Kakihana (1989) Boron isotopic compositions of some boron minerals. Geochim. Cosmochim. Acta 53, 3189.

Osmond, J.K., J.B. Cowart, and M. Ivanovich (1983) Uranium isotopic disequilibrium in ground water as an indicator of anomalies. Int. J. Appl. Radiat. Isot. 34, 283.

Paces, T. (1983) Rate constants of dissolution derived from the measurements of mass balance in hydrological catchments. Geochim. Cosmochim. Acta 47, 1855.

Palmer, M.R. and N.C. Sturchio (1990) The boron isotope systematics of the Yellowstone National Park (Wyoming) hydrothermal system: A reconnaissance. Geochim. Cosmochim. Acta 54, 2811.

Paul, M., A. Kaufman, M. Margaritz, D. Fink, W. Henning, R. Kaim, W. Kutschera, and O. Meirav (1986) A new ${ }^{36} \mathrm{Cl}$ hydrologic model and ${ }^{36} \mathrm{Cl}$ systematics in the Jordan River/Dead Sea system. Nature 321, 511.

Pauling, L. (1960) The Nature of the Chemical Bond. Third Edition. Cornell University Press, Ithaca, New York. 
Pavich, M.J., L. Brown, J.N. Valette-Silver, J. Klein, and R. Middleton (1985) ${ }^{10}$ Be analysis of a Quaternary weathering profile in the Virginia Peidmont. Geology $13,39$.

Pearce, A.J., M.K. Stewart, and M.G. Sklash (1986) Storm runoff generation in humid headwater catchments, 1 , Where does the water come from? Water Resjur. Res. 22, 1263.

Pearson, F.J., W. Balderer, H.H. Loosli, B.E. Lehmann, A. Matter, Tj. Peters, H. Schmassmann, and A. Gautschi (1991) Applied Isotope Hydrogeology - A Case Study in Northern Switzerland. Elsevier Publishers, Amsterdam.

Peterman, Z.E., J.S. Stuckless, S.A. Mahan, B.D. Marshall, E.D. Gutentag, and J.S. Downey (1992) Strontium isotope characterization of the Ash Meadows groundwater system, southern Nevada, USA. In: Kharaka, Y.K. and A.S. Maest (1992) Water-Rock Interaction, Proceedings of the 7th International Symposium on Water-Rock Interaction, Balkema Publishers, Rotterdam, p. 825.

Pettijohn, F.J. (1975) Sedimentary Rocks. Third Edition. Harper and Row, New York. p. 212.

Phillips , F.M., F. Goff, F. Vuataz, H.W. Bentley, D. Elmore, and H.E. Gove (1984) ${ }^{36} \mathrm{Cl}$ as a tracer in geothermal systems: Example from Valles caldera, New Mexico. Geophys. Res. Lett. 11, 1227.

Phillips, F.M., H.W. Bentley, S.N. Davis, D. Elmore, and G. Swanick (1986) Chlorine-36 dating of very old groundwater 2. Milk River aquifer, Alberta, Canada. Water Resour. Res. 22, 2003.

Phillips, F.M., J.L. Mattick, T.A. Duval, D. Elmore, and P.W. Kubik (1988) Chlorine-36 and tritium from nuclear weapons fallout as tracers for long-term liquid and vapor movement in desert soils. Water Resour. Res. 24, 1877.

Piepgras, D.J. and G.J. Wasserberg (1985) Strontium and neodymium isotopes in hot springs on the East Pacific Rise and Guaymas Basin. Earth Planet. Sci. Lett. $72,341$.

Plummer, L.N. and W. Back (1980) The mass balance approach: Application to interpreting the chemical evolution of hydrologic systems. Am J. Sci. 280, 130.

Plummer, L.N., E.C. Prestemon, and D.L. Parkhurst (1991b) An interactive code (NETPATH) for modeling net geochemical reactions along a flow path. U.S. Geological Survey Water-Resources Investigations Report 91-4078.

Plummer, L.N., E.C. Prestemon, and D.L. Parkhurst (1992) NETPATH: An interactive code for interpreting NET geochemical reactions from chemical and 
isotopic data along a flow PATH. In: Kharaka, Y.K. and A.S. Maest (1992) Water-Rock Interaction, Proceedings of the 7th International Symposium on Water-Rock Interaction, Balkema Publishers, Rotterdam, p. 239.

Plummer, L.N., J.F. Busby, R.W. Lee, B.B. Hanshaw (1991a) Geochemical modeling of the Madison aquifer in parts of Montana, Wyoming, and South Dakota. Water Resour. Res. 26, 1981.

Plummer, L.N., Parkhurst, D.L., Thorstenson, D.C. (1983) Development of reaction models for groundwater systems. Geochim. Cosmochim. Acta 47, 665.

Purdy, C.B., A.C. Mignerey, G.R. Helz, D.D. Drummond, P.W. Kubik, D. Elmore, and T. Hemmick (1987) ${ }^{36} \mathrm{Cl}$ : A tracer in groundwaters in the Aquia Formation of southern Maryland. Nucl. Instr. Meth. Phys. Res. B29, 372.

Robson, A. and C. Neal (1990) Hydrograph separation using chemical techniques: An application to catchments in mid-Wales. J. Hydrol. 116, 345.

Roman, D and J. Fabryka-Martin (1988) Iodine-129 and chlorine-36 in uranium ores 1. Preparation of samples for analysis by AMS. Chem. Geol. Isot. Geosci. $72,1$.

Schwarcz, H.P., E.K. Agyei, and C.C. McMullen (1969) Boron isotopic fractionation dưring adsorption from seawater. Earth Planet. Sci. Lett. 6, 1.

Sklash, M.G., M.K. Stewart, and A.J. Pearce (1986) Storm runoff generation in humid headwater catchments 2 . A case study of hillslope and low-order stream response. Water Resour. Res. 22, 1263.

Smalley, P.C., A. Lonoy, and A. Raheim (1992) Spatial ${ }^{87} \mathrm{Sr} /{ }^{86} \mathrm{Sr}$ variations in formation water and calcite from the Ekofisk chalk oil field: Implications for reservoir connectivity and fluid composition. Appl. Geochem. 7, 341.

Smalley, P.C., A. Raheim, J.A.D. Dickson, and D. Emery (1988) ${ }^{87} \mathrm{Sr} / 86 \mathrm{Sr}$ in waters from the Lincolnshire Limestone aquifer, England, and the potential of natural strontium isotopes as a tracer for a secondary recovery seawater injection process in oilfields. Appl. Geochem. 3, 591.

Spivack, A.J. (1985) Boron isotope marine geochemistry. Conf. Int. Les Isotopes dans le Cycle Sedimentaire, Obernai. Cited in: Hoefs, J. (1987) Stable Isotope Geochemistry, Third Edition. Springer-Verlag, Berlin.

Spivack, A.J. and J.M. Edmond (1987) Boron isotope exchange between seawater and ocean crust. Geochim. Cosmochim. Acta 51, 1033. 
Spivack, A.J., M.E. Berndt, and W.E. Seyfried, Jr. (1990) Boron isotope fractionation during supercritical phase separation. Geochim. Cosmochim. Acta $54,2337$.

Spivack, A.J., M.R. Palmer, and J.M. Edmond (1987) The sedimentary cycle of the boron isotopes. Geochim. Cosmochim. Acta 51, 1939.

Starinsky, A., M. Bielski, A. Ecker, and G. Steinitz (1983b) Tracing the origin of salts in groundwater by $\mathrm{Sr}$ isotopic composition (The crystalline complex of the southern Sinai, Egypt. Chem. Geol. Isot. Geosci. 1, 257.

Starinsky, A., M. Bielski, B. Lazar, G. Steinitz, and M. Raab (1983a) Strontium isotope evidence on the history of oilfield brines, Mediterranean Coastal Plain, Israel. Geochim. Cosmochim. Acta 47, 687.

Stauffer, R.E. and B.D. Wittchen (1991) Effects of silicate weathering on water chemistry in forested, upland, felsic terrane of the USA. Geochim. Cosmochim. Acta 55, 3253.

Stueber, A.M., L.M. Walter, T.J. Huston, and P. Pushkar (1993) Formation waters from Mississippian-Pennsylvanian reservoirs, Mlinois basin, USA: Chemical and isotopic constraints on evolution and migration. Geochim. Cosmochim. Aeta 57, 763.

Stueber, A.M., Pushkar, P., and E.A. Hetherington (1987) A strontium isotopic study of formation waters from the Illinois basin, USA. Appl. Geochem. 2, 477.

Swihart, G.H., P.B. Moore, E.L. Callis (1986) Boron isotopic composition of marine and non-marine evaporite borates. Geochim. Cosmochim. Acta 50, 1297.

Taylor, S.R. and S.M. McLennan (1985) The Continental Crust: Its Composition and Evolution. Blackwell Scientific Publications, Oxford.

Torgerson, T., M.A. Habermehl, F.M. Phillips, D. Elmore, P. Kubik, B.G. Jones, T. Hemmick, and H.E. Gove (1991) Chlorine 36 dating of very old groundwater 3. Further studies in the Great Artesian Basin, Australia. Water Resour. Res. 27, 3201.

Turekian, K.K. (1968) Oceans. Prentice-Hall, Englewood Cliffs, New Jersey.

Vengosh, A., A. Starinsky, Y. Kolodny, A.R. Chivas, and M. Raab (1992) Boron isotope variations during fractional evaporation of sea water: New constraints on the marine vs. nonmarine debate. Geology $20,799$.

Vengosh, A., A. Starinsky, Y. Kolodny, and A.R. Chivas (1991b) Boron isotope geochemistry as a tracer for the evolution of brines and associated hot springs from the Dead Sea, Israel. Geochim. Cosmochim. Acta 55, 1689. 
Vengosh, A., A.R. Chivas, M.T. McCulloch, A. Starinsky, and Y. Kolodny (1991a) Boron isotope geochemistry of Australian salt lakes. Geochim. Cosmochim. Acta 55, 2591.

Wedepohl, K.H. (1969) Handbook of Geochemistry. Springer-Verlag, Berlin.

Wels, C., R.J. Cornett, and B.D. Lazerte (1991) Hydrograph separation: A comparison of geochemical and isotopic tracers. J. Hydrol. 122, 253.

White, A.F., A.E. Blum, T.D. Bullen, M.L. Peterson, M.S. Schulz, and J.W. Harden (1992) A three million year weathering record for a soil chronosequence developed in granitic alluvium, Merced, California, USA. In: Kharaka, Y.K. and A.S. Maest (1992) Water-Rock Interaction, Proceedings of the 7th International Symposium on Water-Rock Interaction, Balkema Publishers, Rotterdam, p. 607.

Wickman, T. and G. Jacks (1992) Strontium isotopes in weathering budgeting. In: Kharaka, Y.K. and A.S. Maest (1992) Water-Rock Interaction, Proceedings of the 7th International Symposium on Water-Rock Interaction, Balkema Publishers, Rotterdam, p. 611.

Williams, A.E., and M.A. McKibben (1989) A brine interface in the Salton Sea Geothermal System, California: Fluid geochemical and isotopic characteristics. Geochim. Cosmochim. Acta 53, 1905.

Wilson, G.V., P.M. Jardine, R.J. Luxmoore, L.W. Zelazny, D.A. Lietzke, and D.E. Todd (1991a) Hydrogeochemical processes controlling subsurface transport from an upper subcatchment of Walker Branch watershed during storm events.

1. Hydrologic transport processes. J. Hydrol. 123, 297.

Wilson, G.V., P.M. Jardine, R.J. Luxmoore, L.W. Zelazny, D.E. Todd, and D.A. Lietzke (1991b) Hydrogeochemical processes controlling subsurface transport from an upper subcatchment of Walker Branch watershed during storm events. 2. Solute transport processes. J. Hydrol. 123, 317.

Xiao, Y., D. Sun, Y. Wang, H. Qi, and L. Jin (1992) Boron isotopic compositions of brine, sediments, and source water in Da Qaidam Lake, Qinghai, China. Geochim. Cosmochim. Acta 56, 1561.

Xiao, Y.K. and E.S. Beary (1989) High-precision isotopic measurement of lithium by thermal ionization mass spectrometry. Int. J. Mass Spec. Ion Proc. 94, 101. 
Table 1

\begin{tabular}{|c|c|c|c|c|c|}
\hline Nuclide & Reported As & $\begin{array}{l}\text { Primary } \\
\text { Production }\end{array}$ & $\begin{array}{l}\text { Half-life } \\
\text { (yrs) }\end{array}$ & Typical Values & $\begin{array}{l}\text { Primary } \\
\text { Production Environment } \\
\text { (hydrologic applications) }\end{array}$ \\
\hline${ }^{3} \mathbf{H}$ & $\begin{array}{l}\text { Activity concentration } \\
\text { or Tritium Units (TU) }\end{array}$ & $\begin{array}{l}\text { (1) Atmospheric: } 14 \mathrm{~N}+\mathrm{n} \rightarrow{ }^{3} \mathrm{H}+{ }^{12} \mathrm{C} \\
\text { (2ithospheric: }{ }^{6} \mathrm{Li}(\mathrm{n}, \alpha)^{3} \mathrm{H} \\
\text { (4) Thermonuclear: various }\end{array}$ & 12.3 & $0.100 \mathrm{TU}$ & $\begin{array}{l}\text { Atmosphere (cosmogenic) } \\
\text { Atmospheric thermonuclear weapons } \\
\text { testing 1950's to 1960's }\end{array}$ \\
\hline $6,7 \mathrm{Ii}$ & $8^{6} \mathrm{Li}$ & Non-radiogenic & Stable & -35 to +15 & Primordial \\
\hline${ }^{3} \mathrm{He}$ & {$\left[{ }^{3} \mathrm{He}\right]$ or ${ }^{3} \mathrm{He}{ }^{\beta} \mathrm{H}$} & ${ }^{3} \mathrm{H} \rightarrow{ }^{3} \mathrm{He}+\beta$ & Stable & $\sim 10^{6}$ atoms $/ \mathrm{g} \mathrm{H}_{2} \mathrm{O}$ & Tritium decay \\
\hline $4 \mathrm{He}$ & {$[4 \mathrm{H}]$} & Neutralization of $\alpha$ & Stable & $-10^{12}$ atoms/g $\mathrm{H}_{2} \mathrm{O}$ & Deep lithosphere \\
\hline 10Be & $\begin{array}{l}{ }^{10} \mathrm{Be}^{\prime \theta} \mathrm{Be} \\
\text { or }\left[{ }^{10} \mathrm{Be}\right]\end{array}$ & $\begin{array}{l}\text { (1) Atmospheric: } \\
\text { Spallation of } \mathrm{O} \text { and } \mathrm{N} \\
\text { Lithospheric: } \\
\text { Spallation of } \mathrm{O}\end{array}$ & $1.5 \times 10^{6}$ & ${ }^{10} \mathrm{Be}^{/ 9} \mathrm{Be}=10^{-7}$ & $\begin{array}{l}\text { Shallow lithosphere } \\
\text { (soils and rock outcrop) }\end{array}$ \\
\hline $10,11 \mathrm{~B}$ & $\delta^{11 B}$ & Non-radiogenic & Stable & -20 to +50 & Primordial \\
\hline $35,37 \mathrm{Cl}$ & $8^{37} \mathrm{Cl}$ & Non-radiogenic & Stable & -1.5 to +1.0 & Primordial \\
\hline $36 \mathrm{Cl}$ & $36 \mathrm{Cl} / \mathrm{Cl}$ & $\begin{array}{l}\text { (1) Atmospheric: } \\
40 \mathrm{Ar}+\mathrm{p} \rightarrow{ }^{36} \mathrm{Cl}+\alpha \\
\text { Lithospheric (and Thermonuclear): } \\
{ }^{55} \mathrm{Cl}(\mathrm{n}, \gamma)^{36} \mathrm{Cl}\end{array}$ & $3.01 \times 10^{5}$ & $10^{15}$ to $10^{-11}$ & $\begin{array}{l}\text { Atmosphere (cosmogenic) } \\
\text { Atmospheric thermonuclear weapons } \\
\text { testing } 1950^{\circ} \text { s to } 1960^{\prime} \text { s } \\
\text { Deep lithosphere }\end{array}$ \\
\hline $41 \mathrm{Ca}$ & $41 \mathrm{Ca} / \mathrm{Ca}$ & $40 \mathrm{Ca}(n, \gamma)^{41} \mathrm{Ca}$ & $1.03 \times 10^{5}$ & $10^{-16}$ to $10^{-13}$ & $\begin{array}{l}\text { Shallow lithosphere } \\
\text { (soils and rock outcrop) }\end{array}$ \\
\hline $87 \mathrm{Sr}$ & $\begin{array}{l}8^{87} \mathrm{Sr} \text { or } \\
{ }^{87} \mathrm{Sr} / 86 \mathrm{Sr}\end{array}$ & $\beta$-decay from $87 \mathrm{Rb}$ & Stable & $8^{87} \mathrm{Sr}=-9.0$ to +130 & Lithosphere \\
\hline 1291 & $129 \mathrm{I} / \mathrm{I}$ & $\begin{array}{l}\text { (1) Atmospheric: } \\
\text { Cosmic radiation } \\
\text { Spallation from Xe } \\
\text { Lithospheric (and Thermonuclear): } \\
\text { spontaneous fission from uranium }\end{array}$ & $1.6 \times 10^{7}$ & $10^{-14}$ to $10^{-10}$ & $\begin{array}{l}\text { Atmosphere (cosmogenic) } \\
\text { Atmospheric thermonuclear weapons } \\
\text { testing } 1950^{\circ} \text { s to } 1960^{\prime} \text { s } \\
\text { Deep lithosphere }\end{array}$ \\
\hline $143 \mathrm{Nd}$ & $\boldsymbol{E}_{\mathrm{Nd}}$ & $\alpha$-decay from ${ }^{147} \mathrm{Sm}$ & Stable & -10 to +10 & Lithosphere \\
\hline $206 \mathrm{~Pb}$ & $206 \mathrm{~Pb}^{204} \mathrm{~Pb}$ & 238U-series decay chain & Stable & 18 to 20 & Lithosphere \\
\hline $207 \overline{\mathrm{Pb}}$ & $207 \mathrm{~Pb} / 204 \mathrm{~Pb}$ & 235 U-series decay chain & Stable & 14.5 to 16 & Lithosphere \\
\hline $208 \mathrm{~Pb}$ & $208 \mathrm{~Pb} / 204 \mathrm{~Pb}$ & $232 T h$-series decay chain & Stable & 37 to 39 & Lithosphere \\
\hline $230 \mathrm{Th}$ & $\left({ }^{230} \mathrm{Th} / 232 \mathrm{Th}\right)_{\mathrm{AR}}$ & $\alpha$-decay from ${ }^{234} U$ & $7.54 \times 10^{4}$ & 1 to 1.4 & Lithosphere \\
\hline $234 \mathrm{U}$ & $(234 \mathrm{U} / 238 \mathrm{U})_{\mathrm{AR}}$ & $\begin{array}{l}\alpha-\text { and } \beta \text {-decay: } \\
234 \mathrm{~Pa}_{\mathrm{a}} \rightarrow 234 \mathrm{U}\end{array}$ & $2.45 \times 10^{5}$ & 0.8 to 5.0 & Lithosphere \\
\hline $238 \mathrm{U}$ & $(234 \mathrm{U} / 238 \mathrm{U})_{A R}$ & Non-radiogenic & $4.468 \times 10^{9}$ & 0.8 to 5.0 & Primordial \\
\hline
\end{tabular}

Notation and definitions:

1) Tritium Unit (TU): $1 \mathrm{TU}=1$ atom of ${ }^{3} \mathrm{H}$ per $10^{18}$ atoms of hydrogen $=7.1$ disintegrations per minute $(\mathrm{dpm})=3.2 \mathrm{pCi}=0.12 \mathrm{~Bq}$

2) $\delta$ notation: $\delta=\{[(a / b)$ sample $/(a / b)$ standard $]-1\} \times 1000$

where:

for $\mathrm{Li}: a=6 \mathrm{Li}, b=7 \mathrm{Li}$; and the reference standard is NBS L-SVEC

for $\mathrm{B}: \mathrm{a}=11 \mathrm{~B}, \mathrm{~b}=10 \mathrm{~B}$; and the reference standard is NBS SRM951

for Cl: $a=37 \mathrm{Cl}, \mathrm{b}=35 \mathrm{Cl}$; and the reference standard is SMOC (standard mean ocean water)

for $S_{r}$ : $a=87 \mathrm{Sr}, b={ }^{86} \mathrm{Sr}$, and the reference standard is present-day seawater $87 \mathrm{Sr} / 86 \mathrm{Sr}=0.7092$

3) $\varepsilon_{\mathrm{Nd}}=\{[(143 \mathrm{Nd} / 144 \mathrm{Nd})$ sample / (143Nd/144Nd)CHUR $]-1\} \times 10000$

CHUR $=$ Chondritite Uniform Reservoir $=0.512636$ 


\section{Table 2}

\begin{tabular}{|c|c|c|c|c|c|c|c|c|c|c|c|}
\hline Element & $\begin{array}{c}\text { Upper } \\
\text { Continental } \\
\text { Crust } \\
\end{array}$ & $\begin{array}{c}\text { Silicic } \\
\text { Granitic } \\
\end{array}$ & $\begin{array}{l}\text { Basalt/ } \\
\text { Gabbro }\end{array}$ & Shale & Sandstone & Limestone & Seawater & $\begin{array}{l}\text { River } \\
\text { Water }\end{array}$ & Rain & $\begin{array}{l}\text { Ground } \\
\text { Water }\end{array}$ & Brines \\
\hline L & 20 & 30 & 17 & 46 & 15 & 5.2 & 0.17 & 0.003 & very low & $<0.5$ & 194 \\
\hline $\mathrm{Be}$ & 3 & 3 & 1 & 2.1 & 0.26 & 0.18 & $6.0 \mathrm{E}-07$ & $1.0 \mathrm{E}-05$ & $1.0 \mathrm{E}-13$ & $<0.05$ & $\cdots$ \\
\hline $\mathrm{B}$ & 15 & 10 & 5 & 194 & 90 & 16 & 4.5 & 0.01 & $\ldots$ & $<3$ & 257 \\
\hline $\mathrm{Al}$ & 80400 & 78326 & 95000 & 80100 & 32100 & 8970 & 0.001 & 0.05 & 0.01 & $<1.5$ & $\cdots$ \\
\hline$a$ & 150 & 160 & 150 & 170 & 15 & 305 & 19000 & 7.8 & $<8$ & $<380$ & 151000 \\
\hline $\mathrm{Ca}$ & 30000 & 27516 & 76000 & 22500 & 22400 & 272000 & 410 & 15 & $<1.4$ & $<140$ & 27400 \\
\hline $\mathbf{F b}$ & 112 & 150 & 130 & 243 & 197 & 46 & 0.12 & 0.001 & $\therefore$ & $<0.1$ & $\cdots$ \\
\hline $\mathrm{Sr}$ & 350 & 250 & 465 & 290 & 28 & 617 & 8 & 0.07 & $<0.005$ & $<200$ & 400 to 3480 \\
\hline 1 & 1 & 0.5 & 0.5 & 3.8 & 4.4 & 1.6 & 0.06 & 0.007 & $<0.003$ & $<0.3$ & 48 \\
\hline $\mathrm{Nd}$ & 26 & 23 & 25 & 18 & 24 & 8 & $2.3 E-06$ & $3.8 \mathrm{E}-05$ & very low & $<0.05$ & $\cdots$ \\
\hline $\mathrm{Pb}$ & 20 & 17 & 6 & 20 & 14 & 16 & $3.0 \mathrm{E}-05$ & 0.001 & $<0.035$ & $<0.1$ & 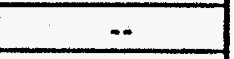 \\
\hline $\mathrm{U}$ & 2.8 & 3 & 2.7 & 4.1 & 1 & 2.2 & 0.003 & $4.0 E-05$ & $\ldots$ & $<10$ & $\cdots$ \\
\hline Th & 10.7 & 14 & 1 & 13 & 3.9 & 0.2 & $5.0 \mathrm{E}-07$ & $<1.0 \mathrm{E}-10$ & very low & $<1.0 E-4$ & $\ldots$ \\
\hline Sources: & [1] & {$[1][2]$} & [2] [3] & [2] [4] & [4] & [4] & [4] [5] & [1] & [2] [4] & [4] (7) & [4] [6] \\
\hline
\end{tabular}




\section{Figure Captions}

Figure 1. The change in $\mathrm{Sr}$ isotopic composition with time in minerals of a typical granitic rock. For all minerals and the whole rock (WR), initial $\left(t_{\phi}\right) \delta^{87} \mathrm{Sr}=$ -6.63. The $\mathrm{Rb} / \mathrm{Sr}$ ratios depicted in this figure are: 83 (biotite), 1.25 (alkali feldspar), 0.30 (hornblende), 0.25 (WR), and 0.08 (plagioclase).

Figure 2. The change in $\mathrm{Pb}$ isotopic composition with time in minerals of a typical granitic rock. For all minerals and the whole rock (WR), initial $\left(t_{\varnothing}\right){ }^{206} \mathrm{~Pb} / 204 \mathrm{~Pb}$ $=18$. The $\mathrm{U} / \mathrm{Pb}$ ratios depicted in this figure are: 0.80 (biotite), 0.06 (alkali feldspar), 2.14 (hornblende), 0.22 (WR), and 25 (plagioclase).

Figure 3. Bowen's Reaction Series. Crystallization of minerals in an evolving magma generally follows two simultaneous paths, represented by the Continuous Series (plagioclase feldspars) and the Discontinuous Series (olivine through biotite). Crystallization of alkali feldspars and quartz occurs at lowtemperatures in more evolved, silicic, magmas. Magma types resulting from crystallization at each interval are represented in the small boxes on the left partion of the figure. The minerals highest in the Reaction Series (e.g., olivine and anorthite) are more susceptible to weathering than those lower in the Reaction Series (e.g., quartz).

Figure 4. Catchment hydrologic processes composing a local hydrologic cycle. Each of these processes can be assessed by lithogenic, cosmogenic, or noble gas nuclides.

Figure 5. ${ }^{36} \mathrm{Cl} / \mathrm{Cl}$ ratios in water from wells in the Wawona catchment of Yosemite National Park, California. Two distinct water types are present, one containing thermonuclear ${ }^{36} \mathrm{Cl}$, and one containing exceptionally low values of ${ }^{36} \mathrm{Cl} / \mathrm{Cl}$. A few intermediate samples may represent mixing of the water masses, or may represent pre-1950's water. The ${ }^{36} \mathrm{Cl} / \mathrm{Cl}$ value from a rain sample collected from Wawona in 1993 is shown. This represents post-bombpulse precipitation, and should be similar to pre-1950's precipitation in the region. 
Figure 6. Delta-87Sr in water from wells in the Wawona catchment of Yosemite National Park, California. Low $\delta^{87} \mathrm{Sr}$ values reflect $\mathrm{Sr}$ isotopic equilibrium with the host rocks $\left(\delta^{87} \mathrm{Sr}=-2.5\right.$ to -3.0 ), whereas the higher values indicate incomplete equilibration and the influence of biotite $\left(8^{87} \mathrm{Sr}>+200\right)$. The biotite-influenced water is younger and has not yet had time to completely react with the host rock.

Figure 7. The change in Nd isotopic composition with time in minerals of a typical silicic garnet gneiss with a chemical composition similar to the granitic rocks depicted in Figures 1 and 2. For all minerals and the whole rock (WR), initial $\left(t_{\phi}\right) \varepsilon_{\mathrm{Nd}}=0.0$. The $\mathrm{Sm} / \mathrm{Nd}$ ratios depicted in this figure are: 0.61 (garnet), 0.22 (biotite), 0.13 (alkali feldspar), 0.16 (WR), and 0.17 (plagioclase). 


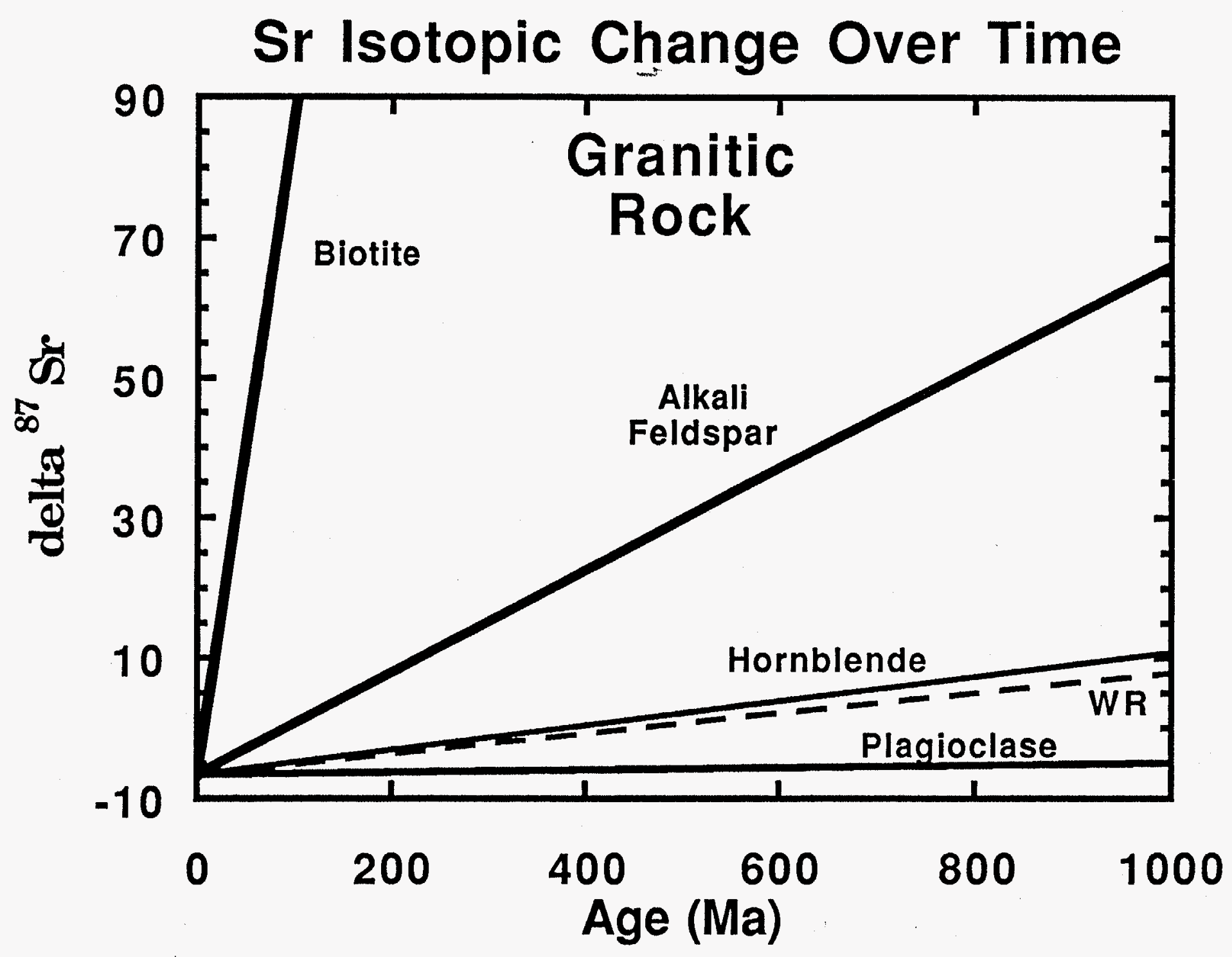

Figure 1 


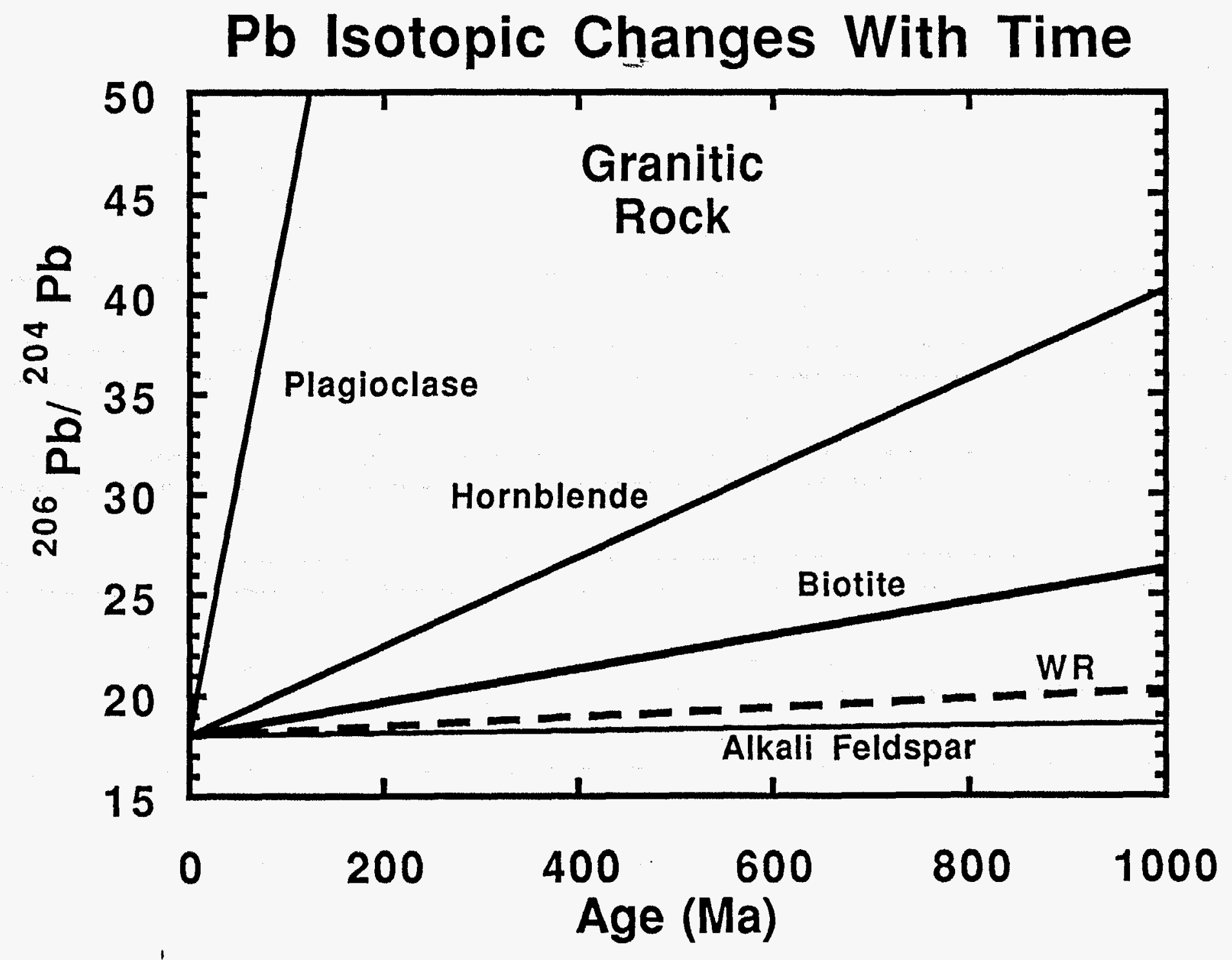

Figure 2 


\section{Bowen's Reaction Series}

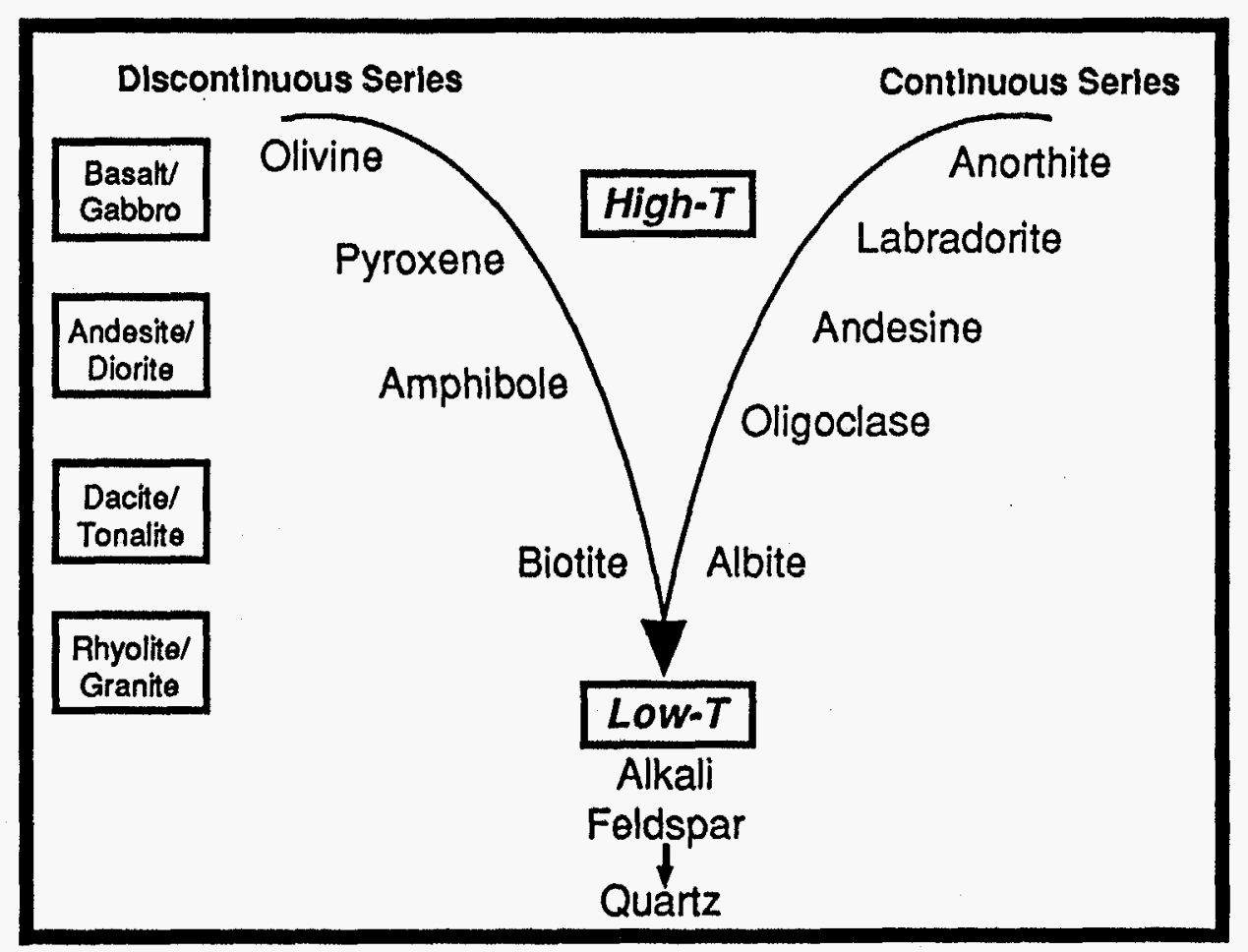

Figure 3 


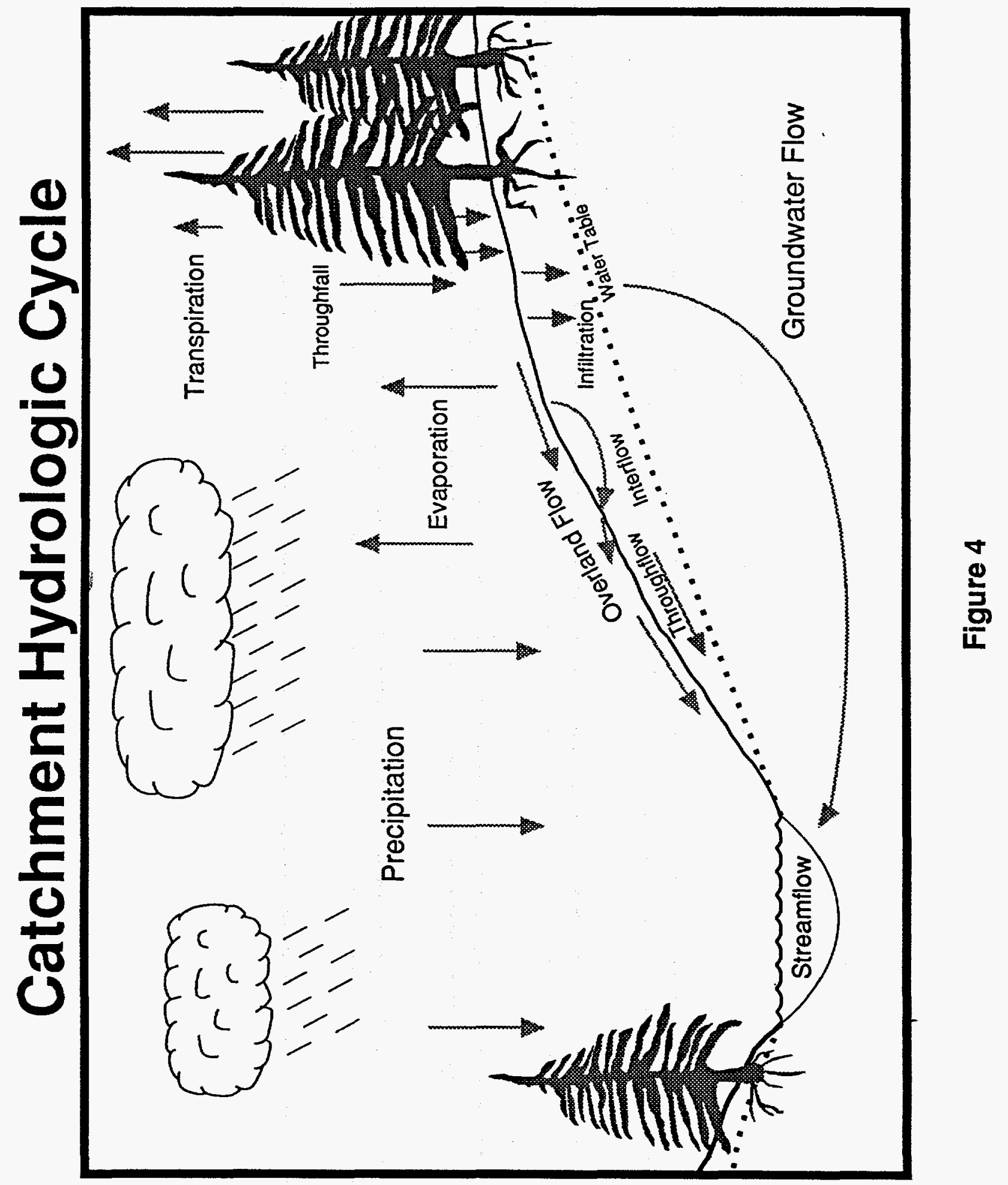




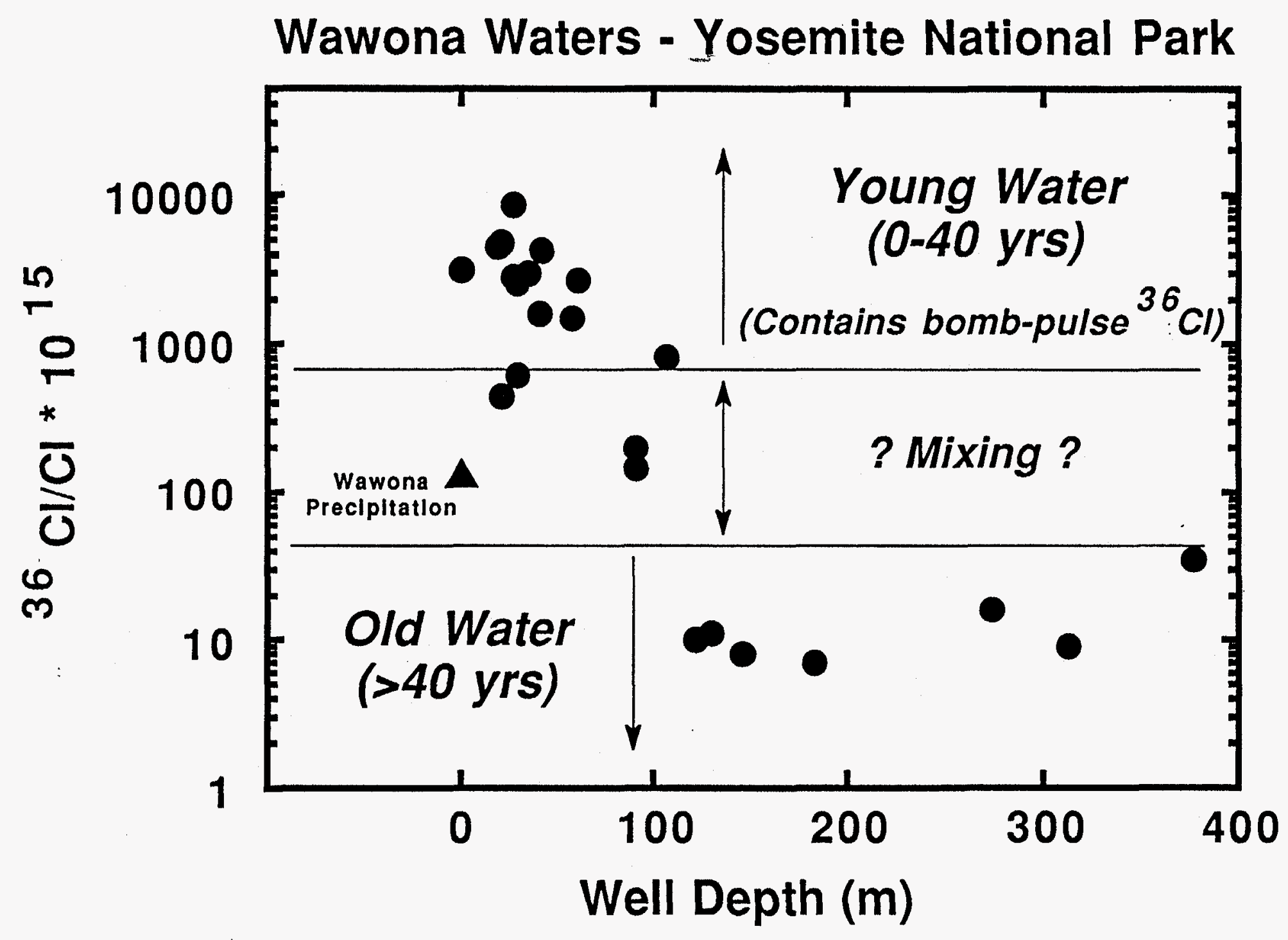

Figure 5 


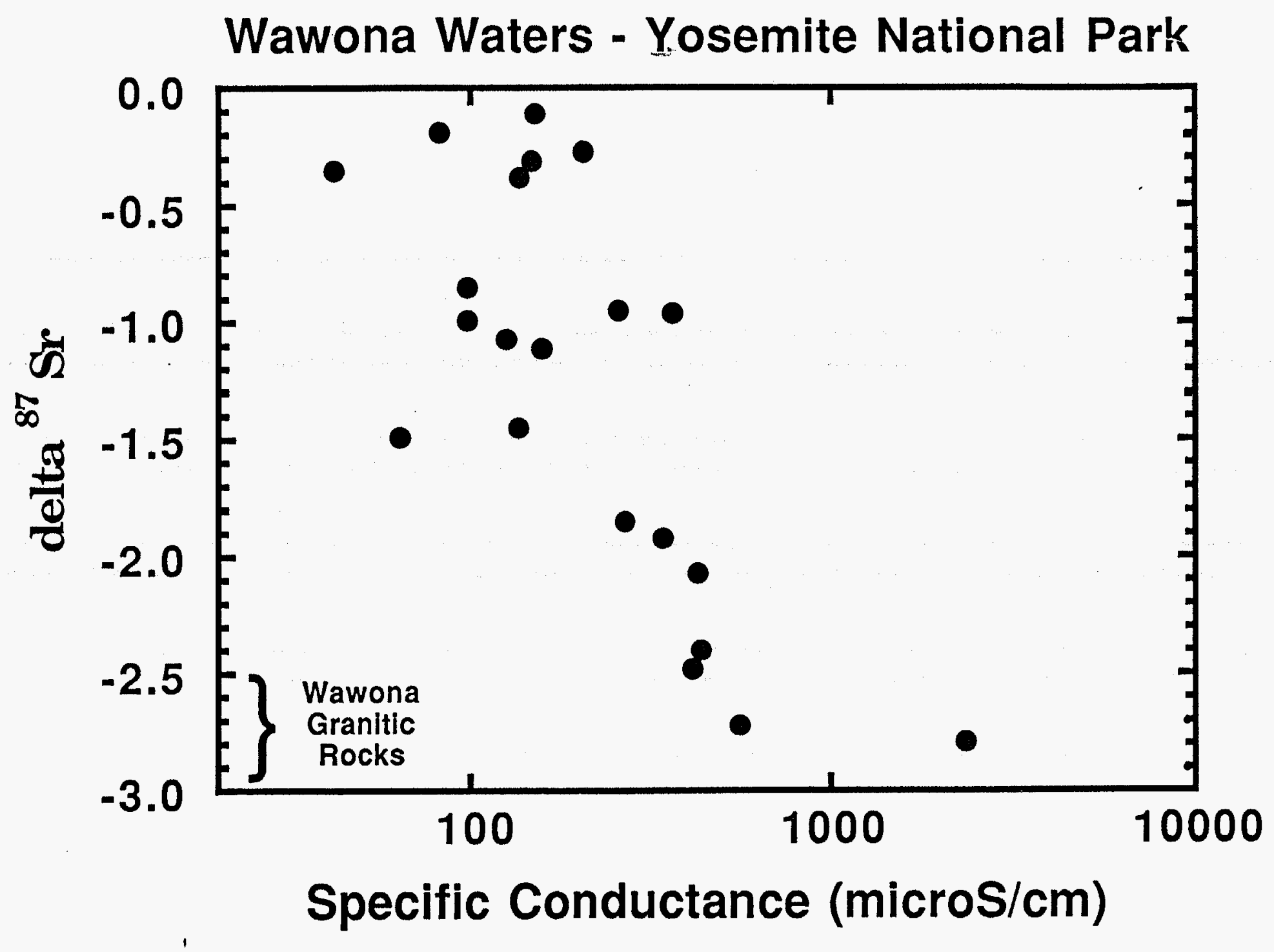

Figure 6 


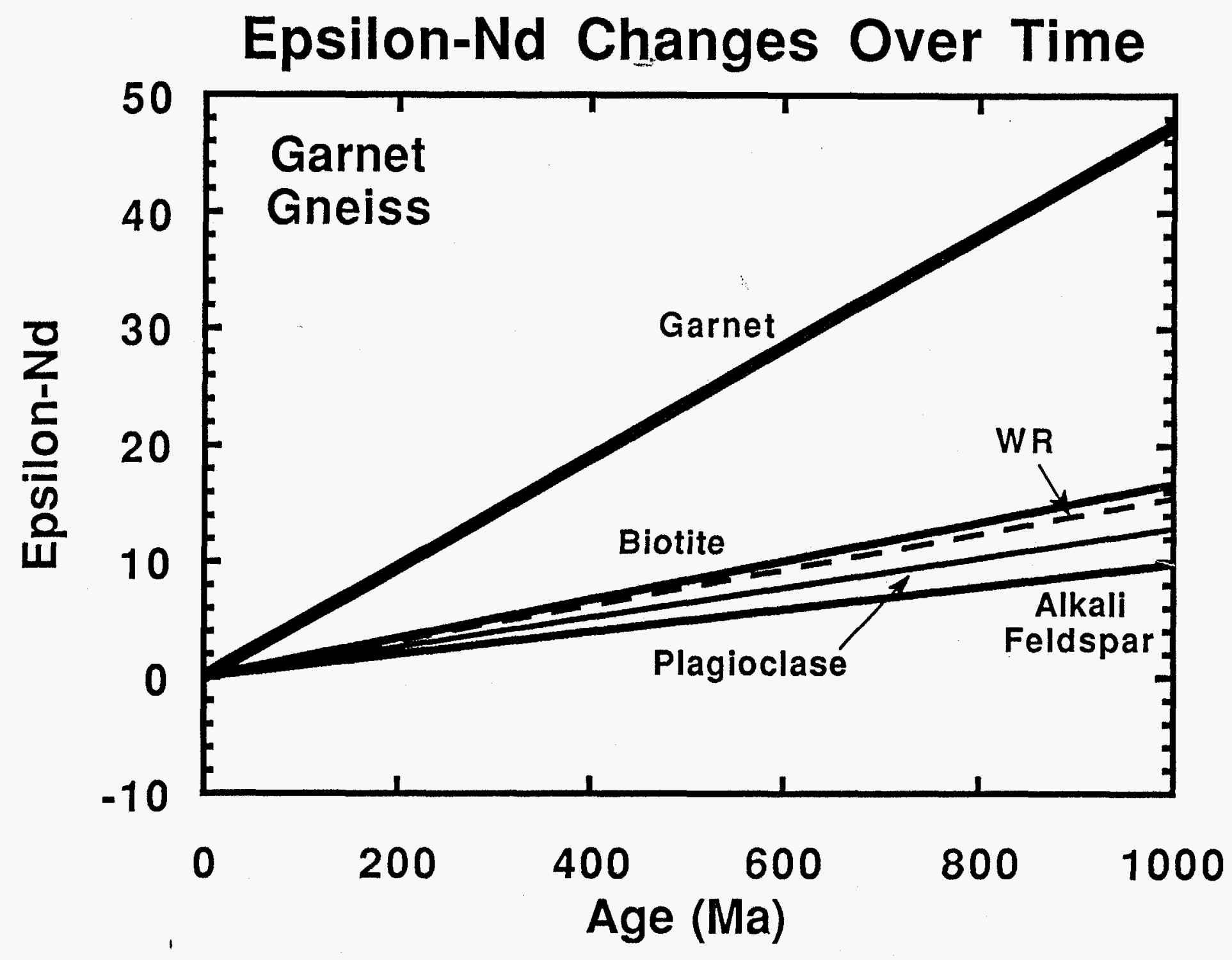

Figure 7 